OPEN ACCESS

Edited by:

Puri Veiga,

University of Porto, Portugal

Reviewed by:

Daniel Pech

The South Border College (ECOSUR),

Mexico

Nicolas Sturaro,

University of Mons, Belgium

*Correspondence:

Soniya Sukumaran

soniya@nio.org

Specialty section: This article was submitted to Marine Evolutionary Biology, Biogeography and Species Diversity, a section of the journal

Frontiers in Marine Science

Received: 30 July 2020 Accepted: 15 October 2020 Published: 12 November 2020

Citation:

Srinivas T, Sukumaran S, Neetu S and Ramesh Babu K (2020) Diversity and Functional Patterns of Benthic Amphipods in the Coralline Intertidal Zones of a Marine National Park, India. Front. Mar. Sci. 7:589195. doi: 10.3389/fmars.2020.589195

\section{Diversity and Functional Patterns of Benthic Amphipods in the Coralline Intertidal Zones of a Marine National Park, India}

\author{
Tatiparthi Srinivas ${ }^{1}$, Soniya Sukumaran ${ }^{1 *}$, S. Neetu ${ }^{2}$ and K. Ramesh Babu ${ }^{3}$ \\ ${ }^{1}$ CSIR-National Institute of Oceanography, Regional Centre, Mumbai, India, ${ }^{2}$ CSIR-National Institute of Oceanography, \\ Panaji, India, ${ }^{3}$ Department of Marine Living Resources, College of Science and Technology, Andhra University, \\ Visakhapatnam, India
}

Coralline intertidal habitats of marine protected areas (MPAs) are important model systems to investigate species diversity and ecological functioning of benthic communities. Spatial variability of amphipod species composition and functional traits were studied over a 3 year period during the summer season at five intertidal transects of the Gulf of Kachchh (GoK) MPAs, India. A total of 22,706 individuals, comprising 71 species belonging to 40 genera and 23 families, were identified. Aoridae, Dexaminidae, Eriopisidae, Lysianassidae, and Maeridae were the best represented families $(68.2 \%$ of total abundance). Distinct spatial patterns in the amphipod assemblage structure and functional traits were observed along the horizontal and vertical axes. The results demonstrated that the amphipod assemblage functioning was greatly influenced by the vertical gradient, with generally higher functional diversity (FD) in the lower intertidal zones suggesting increased diversity in resource use strategies, whereas the upper zones showed very little FD possibly due to the prevalence of environmental filtering. As higher species and functional diversities promote better resource partitioning and resilience of the ecosystem, these results are important for the management of MPAs facing the dual challenges of global climate change and anthropogenic pressures.

Keywords: intertidal, amphipod, vertical zonation, functional traits, fuzzy coding, Marine National Park

\section{INTRODUCTION}

Intertidal habitats are dynamic marine environments present at the interface of sea and land and encompass numerous environmental gradients (Underwood, 2000; Pandey and Thiruchitrambalam, 2018). Horizontal variation in floral and faunal composition in intertidal habitats is determined by a combination of biotic interactions, abiotic factors, dispersal processes, and priority effects (i.e., competitive dominance given by early colonization) (Catalán et al., 2020). Apart from the strong spatial horizontal variations, the characteristic feature of regular alternation of high and low tides also causes ubiquitous patterns of species distribution along the vertical axis (i.e., vertical zonation) (Valdivia et al., 2011; Catalán et al., 2020). A strong gradient of environmental conditions such as desiccation, thermal stress, food, and shelter from predators support clear intertidal zonation patterns of diverse intertidal organisms. 
Significant works conducted on the diversity and distributional trends of organisms along the vertical axis on intertidal habitats have resulted in the establishment of diverse models on distribution patterns of various benthic communities (Araújo et al., 2005). Critical tidal levels (upper shore, middle shore, and lower shore) are primary determinants in establishing the community zonation patterns of intertidal organisms (Southward, 1958; Lewis, 1964; Newell, 1970).

Intertidal zones are susceptible to the potential effects of climate change as these zones naturally face varying environmental conditions and hydrodynamic forcing (Harley et al., 2006). Hence, the knowledge on the complex patterns presented by its inhabitants is critical toward management of these areas and provides a basis for predicting the impacts of climate change. Quantitative information of distribution patterns of different faunal groups is intrinsic to facilitate adequate and representative conservation of biodiversity (Blanchette et al., 2008), more so in coralline intertidal marine protected areas (MPAs). Despite its ecological importance, the tropical coralline intertidal is a poorly understood ecosystem and hence requires multi-pronged studies investigating its abiotic and biotic components and their interactions for evolving effective management strategies (Sindorf et al., 2015).

While the identity of organisms is important to study the community structure, it is also equally essential to understand their functioning within the ecosystem. Functional characteristics of macrobenthos, being an important link connecting biodiversity and ecosystem functioning, are gaining more credence in ecological studies (Wong and Dowd, 2015). It is often beneficial to combine biological trait analysis (BTA) techniques along with the routine diversity studies to gain a better understanding of the structural and functional dynamics of the macrobenthic communities (Bremner, 2005). Changes in functional diversity (FD) are more relied upon now than before to evaluate the impact of various disturbances on the ecology. Systems with high taxonomical and FD are considered to be balanced and impervious to environmental fluctuations (Bellwood et al., 2003).

Among the ecologically important benthic groups that abound in the coralline intertidal zones, Amphipoda are one of the most diverse and abundant peracarid crustacean groups (Thomas, 1993; Conlan, 1994; de-la-Ossa-Carretero et al., 2012). In addition, they constitute a significant source of food for many higher trophic level organisms (Duffy, 2006; Sanz-Lázaro and Marín, 2011; Legeżyńska et al., 2012) and also act as important contributor of marine benthic productivity (Conradi and Cervera, 1995; Guerra-García et al., 2014). Benthic amphipods are known to play significant role in mineralization of sediment through their bio irrigation and feeding activities (Paz-Ríos and Ardisson, 2018). They are used in many marine monitoring studies as indicators of pollution due to their sensitivity to various environmental disturbances (de-la-Ossa-Carretero et al., 2012, 2016). Due to the lack of a pelagic larval stage and their infaunal behavior, benthic amphipods display low dispersion capabilities causing high levels of endemism and high species diversity in a small geographical area (Paz-Ríos et al., 2019). Intertidal zones are one of the most preferred habitats for many species of benthic amphipods (Surya Rao, 1972) and this group exhibits a variety of lifestyles that display clear habitat preferences (McLachlan, 1983; Wildish, 1988; Brown and McLachlan, 1990; Yu et al., 2002).

Unlike the Polychaeta, the Amphipoda has received scant attention and very little is known on their distribution, ecology, and functioning from the Indian subcontinent (Srinivas et al., 2019). The biodiversity of amphipods in estuaries, intertidal, and shallow coastal areas from east and west coasts of India has been increasingly investigated during the last decade (GuerraGarcía et al., 2010; Mondal et al., 2010; Rehitha et al., 2019). The documented information available so far is restricted to taxonomical studies including descriptions of new taxa (Myers et al., 2018, 2019), inventory of species (Lyla et al., 1998; GuerraGarcía et al., 2010), and community structure of amphipods from estuarine and shallow coastal habitats (Nair et al., 1983; Mondal et al., 2010; Raja et al., 2013).

The present study is the first attempt at describing the diversity, distributional, and functional patterns of benthic amphipods in the coralline habitats of the Gulf of Kachchh (GoK), which is a relatively well-conserved coral reef ecosystem in the Indian subcontinent. Since its establishment as a Marine National Park in 1980 and as a Sanctuary in 1982 (MNPS), this reef ecosystem has been subjected to various biodiversity surveys, primarily of corals (Adhavan et al., 2014; Kumar et al., 2014), seagrass (Kamboj, 2014), seaweeds (Roy et al., 2015), reef-dependent ichthyofauna (Parmar et al., 2015), brachyurans (Trivedi et al., 2012), and a brief exploration on macrobenthic communities from shallow coastal environments (Sukumaran et al., 2013). Despite their ecological significance, so far, the amphipods have not been investigated. Species inventories and distribution patterns of major faunal groups are essential for the success of long-term monitoring programs and to develop effective management strategies for sensitive biomes like the tropical coralline zones. Hence, this study was designed to analyze the species distribution and functional patterns of benthic amphipods along the horizontal and vertical gradients of five intertidal transects of the GoK MNPS (Figure 1). We hypothesized distinct variations in amphipod diversity along the vertical gradient of the intertidal zones. It was also expected that the vertical variations would be prominent than horizontal patterns. We further investigated whether the amphipod functional patterns mirrored that of taxonomic diversity? To check the consistency of patterns the sampling was repeated for three consecutive years, i.e., 2016, 2017, and 2018.

\section{MATERIALS AND METHODS}

\section{Study Site}

The GoK is a semi-enclosed sea located in the north-eastern part of the Arabian Sea, occupying a total area of about $7350 \mathrm{~km}^{2}$ and has one of the four major reef ecosystems of the country on its southern coast. To protect its unique marine ecosystem, an area which extends from Okha $\left(22^{\circ} 30^{\prime} \mathrm{N}, 69^{\circ} 00^{\prime} \mathrm{E}\right)$ in the west, to Navlakhi $\left(22^{\circ} 30^{\prime} \mathrm{N}, 70^{\circ} 40^{\prime} \mathrm{E}\right)$ in the east, has been designated as MNPS during 1980-1982 under the provisions of the Wildlife (Protection) Act, 1972 of India (Dixit et al., 2010). The MNPS 


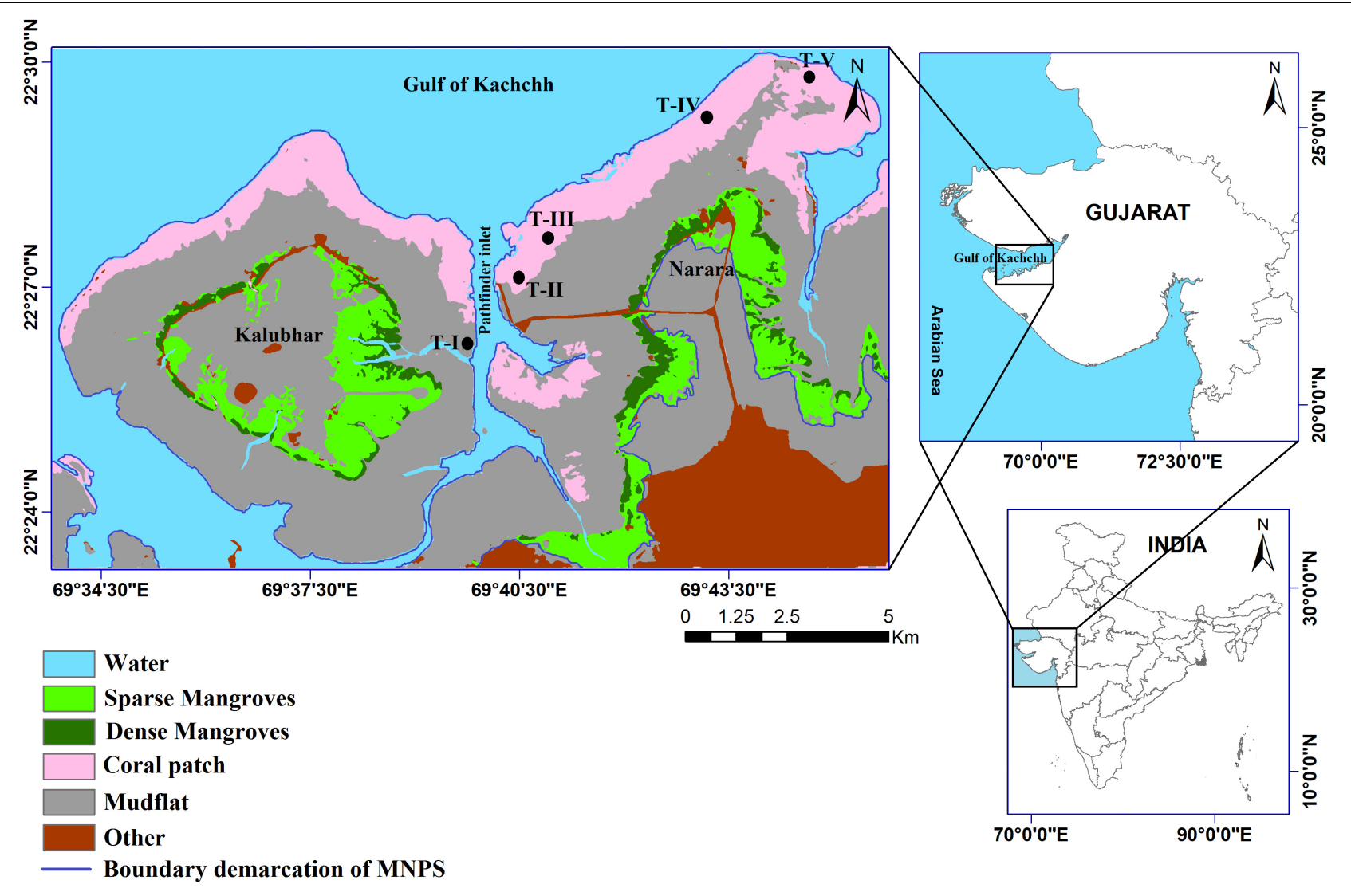

FIGURE 1 | Study area showing the sampling transects along the Gulf of Kachchh Marine National Park and Sanctuary.

supports diverse habitats; including coral reefs, mangrove forests, sandy beaches, mudflats, creeks, rocky coast, sea grass beds, and wide intertidal regions (Satyanarayana and Ramakrishna, 2009). Tides in the GoK are of mixed, predominantly semi-diurnal in nature with a large diurnal inequality (Dixit et al., 2010). Climate of the MNPS is hot and humid and temperature ranges from $7.8^{\circ} \mathrm{C}$ during winter to $44.8^{\circ} \mathrm{C}$ during summer (Sukumaran et al., 2013). The characteristics of less rain and more evaporation make the Gulf waters more saline (36 to 44.5). The GoK has one major port, several intermediate and minor ports, fishing harbors, and Single Point Moorings (SPM) associated with oil refineries, in addition to jetties, breakwaters, submarine pipelines, marine intake, and outfall points (National Institute of Oceanography [NIO], 2018).

Five intertidal locations were selected along the Kalubhar (one site on eastern part of the Island; T-I) and Narara islands (four sites; T-II, T-III, T-IV, and T-V) (Figure 1). Kalubhar and Narara reefs are integral part of MNPS and consist of dense patches of corals in their subtidal and intertidal zones. Narara Bet (Island) is a tidal wetland, attached to the mainland. The eastern side of the bet is separated from Sikka reef by Gagwa creek whereas the western side of the bet is separated from Kalubhar Island by Pathfinder inlet. The tidal maximum during the spring tide is $4.85 \mathrm{~m}$ and during neap tide, it is about $2.65 \mathrm{~m}$. Therefore, during the low tide, the intertidal flat is exposed for about 3-5 km, and has substrata that are mainly sandy, rocky, and small mudflats. Kalubhar is a rectangle type island, bordered by mangrove formations and broad encircled reef areas. The island is separated from the mainland by the Salaya creek in the west, the Pathfinder Inlet in the south and east with Gulf to the north. In order to better understand the habitat structure of the studied intertidal transects, prior to sample collection, an overview of the area was made from high water level to low water level. The intertidal region at T-I is exposed about $1.5 \mathrm{~km}$ long. Here, mud is the major benthic component observed from the lower to upper shore. The intertidal expanses of T-II to T-V ranged from 2 to $2.5 \mathrm{~km}$, comprising large number of coral colonies and their associated flora and fauna at their lower shore level. At the middle shore of these transects, rocks and boulders covered with silt were the dominant benthic component. The higher intertidal regions of T-II to T-V had mainly mangrove mud.

\section{Sampling}

For this study, the intertidal areas were divided into three zones, i.e., upper shore (henceforth HW), middle shore (henceforth MW), and lower shore (henceforth LW). Sampling was constrained during the summer season (April-May) for three consecutive years $(2016,2017$, and 2018) to avoid seasonal influences in species distributional patterns. At all transects with 
TABLE 1 | List of functional traits and modalities used in this study along with corresponding codes with indication of the rational for the selection of the traits.

\begin{tabular}{|c|c|c|c|}
\hline $\begin{array}{l}\text { Functional } \\
\text { Trait }\end{array}$ & $\begin{array}{l}\text { Trait } \\
\text { Modalities }\end{array}$ & Codes & Rationale for functional traits selection \\
\hline Mobility (M) & $\begin{array}{l}\text { Discretely motile } \\
\text { Motile }\end{array}$ & $\begin{array}{l}\text { M.D } \\
\text { M.M }\end{array}$ & $\begin{array}{l}\text { Despite the generally low mobility characteristic of macrobenthic invertebrates (Warwick, 1993), the small- } \\
\text { scale mobility of these organisms is essential for the ecology of benthic communities not only regarding } \\
\text { the avoidance of physical disturbance (Hinchey et al., 2006) but also in the prey-predatory activities } \\
\text { Piló et al., 2016). }\end{array}$ \\
\hline Habitat (H) & $\begin{array}{l}\text { Free living } \\
\text { Tube building } \\
\text { Burrowing }\end{array}$ & $\begin{array}{l}\text { H.F } \\
\text { H.T } \\
\text { H.B }\end{array}$ & $\begin{array}{l}\text { Indicates food source availability, influences bioturbation processes and may indicate disturbance. When } \\
\text { disturbance increases, only species with specific combinations of traits suitable for survival pass through the } \\
\text { environmental filter (Southwood, 1977). For instance, burrow and tube dwellers are expected to increase after } \\
\text { disturbance (e.g. anoxic conditions, organic pollution), as opposed to surface dwelling species, as they have } \\
\text { some protection from tube or burrow linings and are more likely to have pumping/irrigation features for } \\
\text { oxygenation (Reise, 2002, van der Linden et al., 2017). }\end{array}$ \\
\hline Feeding mode (F) & $\begin{array}{l}\text { Detritus feeders } \\
\text { Suspension feeders } \\
\text { Subsurface deposit feeder } \\
\text { Browsers } \\
\text { Grazers } \\
\text { Scavengers } \\
\text { Predators }\end{array}$ & $\begin{array}{l}\text { F.DT } \\
\text { F.SU } \\
\text { F.SSDE } \\
\text { F.BR } \\
\text { F.GR } \\
\text { F.SC } \\
\text { F.PR }\end{array}$ & $\begin{array}{l}\text { Reflects the trophic structure, resources distribution and how organisms adapt to the residential habitat } \\
\text { (Bremner, 2008; Webb et al., 2009). Trophic diversity is higher in healthy environment owing to the presence } \\
\text { of higher species diversity whereas it decreases in disturbed environment due to the dominance of } \\
\text { opportunistic species (Gamito and Furtado, 2009). }\end{array}$ \\
\hline Bioturbation (B) & $\begin{array}{l}\text { Surface modifiers } \\
\text { Biodiffusors } \\
\text { Epifauna }\end{array}$ & $\begin{array}{l}\text { B.S } \\
\text { B.B } \\
\text { B.E }\end{array}$ & $\begin{array}{l}\text { Bioturbation, also known to have an ecosystem engineering function (Kristensen et al., 2012) is strongly } \\
\text { linked with an organism's mobility (Pearson, 2001) and mode of feeding that cause movement of sediment } \\
\text { particles within the habitat (Dauwe et al., 1998). }\end{array}$ \\
\hline Size (S) & $\begin{array}{l}\text { Very small }(<1 \mathrm{~cm}) \\
\text { Small }(1-2 \mathrm{~cm}) \\
\text { Small-medium }(3-10 \mathrm{~cm})\end{array}$ & $\begin{array}{l}\text { S.Vs } \\
\text { S.S } \\
\text { S.S-M }\end{array}$ & $\begin{array}{l}\text { Defines and associates with other biological traits, mediates other structuring interactions (Mouillot et al., 2006; } \\
\text { Webb et al., 2009). Small-bodied invertebrates may characterise environments with high instability, } \\
\text { consequence of abiotic pressures imposed on the organisms (Mouillot et al., 2006). This biometric parameter } \\
\text { can be more responsible for the trophic structure than taxonomic identity itself (Jennings et al., 2001). }\end{array}$ \\
\hline
\end{tabular}

the exception of T-I, the samples were collected during spring low tides using a quadrat of $20 \times 20 \mathrm{~cm}\left(0.04 \mathrm{~m}^{2}\right)$ at each zone (considered as station). At T-I, due to the difficulty in walking over the vast stretches of soft mud, the sediment samples were collected by boat during spring high tides using a van Veen grab $\left(0.04 \mathrm{~m}^{2}\right)$. To avoid bias in the results by using different sampling methods between different transects (transect T-I vs other transects), similar area, i.e., $0.04 \mathrm{~m}^{2}$ was sampled.

During 2016 and 2017, the sediment samples were collected in triplicates at each location, whereas in 2018 the samples were collected in quadruplicates. In quadrat sampling method, all the surface sediment was scraped to a depth of $10 \mathrm{~cm}$ and collected in a 500 microns mesh sieve. Similarly in grab sampling method too, upper $10 \mathrm{~cm}$ sediment was collected and transferred to a 500 microns mesh sieve. Later the collected sediment samples were sieved and all the organisms retained on sieve were transferred to a plastic bag and preserved with 5\% formalin mixed with Rose Bengal solution. In the laboratory, the samples were sieved again and the amphipod crustaceans were separated from the rest of the macrobenthic groups. The separated amphipods were quantified and identified to a lower taxonomic level by using standard identification keys (Barnard, 1979; Lincoln, 1979; Lyla et al., 1998).

\section{Data Analysis}

The mean abundance of amphipods collected from the all replicate samples at each shore level was expressed as number of individuals per $\mathrm{m}^{2}$ (ind $\mathrm{m}^{-2}$ ). The amphipod abundance data were subjected to univariate diversity measures [e.g., total average abundance $-N$; Margalef's richness index- $d$; Pielou's evenness Index-J'; and Shannon-Wiener diversity index$\left.H^{\prime}\left(\log _{2}\right)\right]$. Analyses of variance (one-way ANOVA) were performed to test for the differences in the univariate diversity measures using Statistica 7. Prior to ANOVA, data were first examined for normality using Shapiro-Wilk's W test. Data were log transformed when the assumptions of variance were significantly different. For multivariate analyses, the mean amphipod abundance data at each shore level were fourthroot transformed to downweight the influence of numerically dominant species, which were used to construct the similarity index using Bray-Curtis similarity coefficient. The spatial distribution of amphipod assemblages was visualized by using non-metric multidimensional scaling (nMDS).

To test for potential significant differences among different transects, zones, and years in amphipod composition, permutational multivariate analyses of variance (PERMANOVA) was performed. A three-way crossed PERMANOVA was 


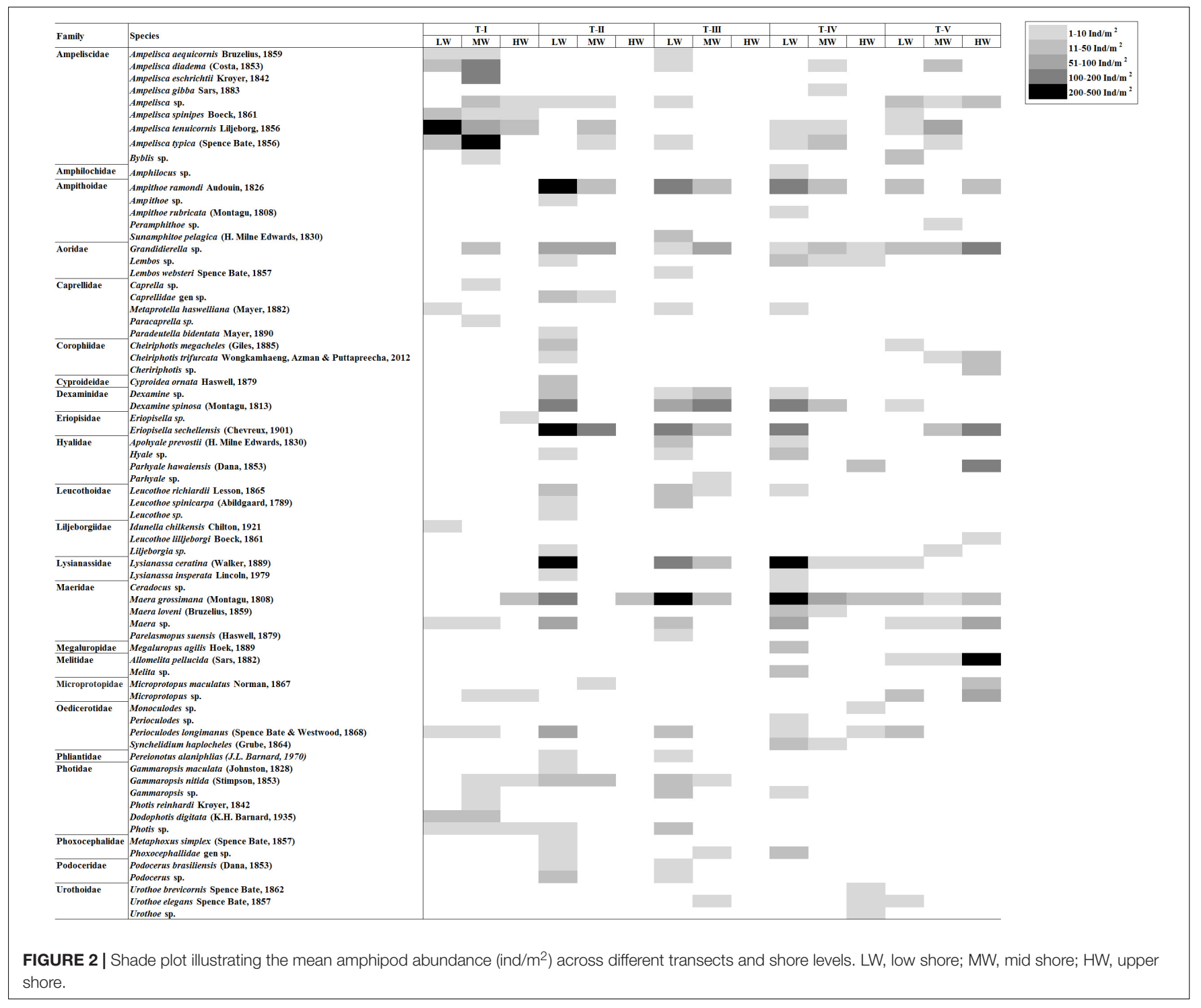

performed on the Bray-Curtis similarity matrix in order to test the null hypothesis of no significant differences in the multivariate structure and composition of amphipod assemblages between the transects, shore levels, and years. The PERMANOVA design included two fixed factors: "shore levels" with three levels (HW, MW, and LW) and "year" with three levels (2016, 2017, and 2018) and one random factor: "transect" with five levels (T-I, T-II, T-III, T-IV, and T-V). Significant terms were investigated using a posteriori pairwise comparisons between transects, shorelines, and years with the PERMANOVA t-statistic and permutations under a reduced model. For the tests, 9999 random permutations were used and a significance level $(p)$ of 0.05 was considered. A similarity percentage analysis (SIMPER) was conducted on fourth root transformed amphipod abundance data to further investigate the amphipod species contributing to the differences between the transects, shorelines, and sampling years. Only species contributing up to $50 \%$ to differences were considered in the analysis, thus focusing on the most common species. All the univariate and multivariate analyses were conducted using the PRIMER v.7 software (Clarke and Gorley, 2015) and PERMANOVA analyses were done using the PERMANOVA + PRIMER add-on package (Anderson et al., 2008).

\section{Biological Trait Analysis (BTA)}

To analyze the functional characteristics of the amphipod assemblages, five traits (mobility, habitat, feeding mode, bioturbation, and body size) subdivided into 18 categories were selected (Table 1). The information of these traits was extracted from a variety of sources, mostly published papers (Macdonald et al., 2010; de-la-Ossa-Carretero et al., 2012; Queirós et al., 2013; Guerra-García et al., 2014) and websites (Biological Traits Information Catalog-BIOTIC, MarLIN, 2006 and Marine Species Traits editorial board, 2019). When information for individual species was not available, data from other species belonging to the same genus were used. 
A fuzzy coding approach was employed wherein a score was assigned to each species according to its affinity with the different functional trait categories (Chevenet et al., 1994). In this procedure, a scale was adopted ranging from 0 to 3 for each trait category, where no affinity was coded as 0 and complete affinity was coded as 3 . To conduct BTA, three different types of data matrices were required: (a) "taxa by station" (taxa abundance at each zone); (b) "taxa by traits" (biological traits for each taxon); and (c) "traits by station" (biological traits at each zone). To achieve the "traits by station" matrix, trait categories for each taxon present at a zone were multiplied by their abundance at that station, and then summed over all taxa present at each station to obtain a single value for each trait category (Bremner et al., 2006). The resulting "traits by station" data matrix was then subjected to Fuzzy correspondence analysis (FCA) analysis to identify the differences in functional composition between transects and zones which was visualized on an FCA plot. FD of amphipod assemblages was estimated by using Rao's quadratic entropy index (Rao, 1982; Paganelli et al., 2012). FCA was performed with R-3.5.1 open-source software with the packages with "ade4" (Dray and Dufour, 2007) and "vegan" libraries (Oksanen et al., 2016).

\section{RESULTS}

\section{Taxonomic Composition}

The samples examined yielded 22,706 individuals of amphipods, 71 species belonging to 40 genera under 23 families (Figure 2 and Supplementary 1). The most speciose families in the study area were Ampeliscidae (nine species) and Photidae (six species) (Figure 2). Five families, viz., Aoridae, Dexaminidae, Eriopisidae, Lysianassidae, and Maeridae recorded high abundances and together constituted $68.2 \%$ of total abundance. Eriopisidae was the most dominant family (18.8\%) throughout the study, which was constituted by two species (Eriopisella sp. and Eriopisella sechellensis) (Supplementary 1). The maerid, Maera grossimana was a distinct inhabitant at various study sites and accounted for $14 \%$ of the total abundance followed by E. sechellensis (12.3\%), Lysianassa ceratina (11.1\%), and Ampithoe ramondi (9.2\%).

\section{Temporal Variation}

Significant shifts in amphipod assemblage structure between different sampling years were evidenced (Pseudo- $\mathrm{F}=2.45$; $p=0.001$ ) (Table 2). Pair-wise combination of different sampling years indicated that 2016 was significantly dissimilar with 2017 $(\mathrm{AvD}=90.70 \%)$ and $2018(\mathrm{AvD}=91.45 \%)$. Variations were insignificant between 2017 and 2018 (AvD = 85.34\%). The dissimilarities between 2016-2017 and 2017-2018 were due to the relative densities of $M$. grossimana, Ampelisca tenuicornis, and Grandidierella sp.; whereas, M. grossimana, Grandidierella sp., and E. sechellensis contributed most to the dissimilarities of 2016-2018 (Supplementary 2A). Among the three study years investigated, maximum amphipod abundance was observed during 2017 (Table 3). No significant variations were observed in univariate diversity indices among different sampling years (Supplementary 3).

\section{Horizontal Spatial Distribution}

The composition of amphipod assemblages varied significantly between the five intertidal sampling transects (Pseudo- $\mathrm{F}=2.65$; $p<0.001$ ) (Table 2). Pair-wise tests indicated that the amphipod assemblages differed significantly between T-I and other transects. Amphipod assemblage structure did not significantly differ between T-II, T-III, T-IV, and T-V. The mean amphipod abundance at different intertidal transects revealed that T-II harbored highest (699 ind $\mathrm{m}^{-2}$ ) abundances, whereas T-I recorded the lowest (359 ind $\mathrm{m}^{-2}$ ) average densities (Figure 3A). More species were observed at T-II and T-IV (34 species each) whereas T-I recorded the lowest species number (23 species) (Supplementary 1). Average Shannon-Weiner diversity $\left(H^{\prime}\right)$ index ranged from $1.8 \pm 1.6$ (T-II, T-III) to $2.6 \pm 0.9$ (T-IV). Higher mean Margalef's species richness $(d)$ was recorded at T-III

TABLE 2 | Results of three-way permutational multivariate analysis of variance (PERMANOVA) based on Bray-Curtis similarities for differences in amphipod assemblages among shorelines (Sh), transects (Tr), and years (Ye) as factors.

\begin{tabular}{lcccc}
\hline Source & $\boldsymbol{d} \boldsymbol{f}$ & MS & Pseudo-F & $\boldsymbol{P}$ (perm) \\
\hline $\mathrm{Sh}$ & 2 & 8405.8 & 3.38 & $\mathbf{0 . 0 0 2 1}$ \\
$\mathrm{Tr}$ & 4 & 5761.1 & 2.65 & $\mathbf{0 . 0 0 0 1}$ \\
Ye & 2 & 7865.7 & 2.45 & $\mathbf{0 . 0 0 1}$ \\
$\mathrm{Sh} \times \mathrm{Tr}$ & 7 & 2534.3 & 1.16 & 0.2197 \\
$\mathrm{Sh} \times \mathrm{Ye}$ & 4 & 3936.9 & 1.81 & $\mathbf{0 . 0 0 5 1}$ \\
$\mathrm{Tr} \times$ Ye & 8 & 3418 & 1.57 & $\mathbf{0 . 0 0 7 9}$ \\
Res & 11 & 2175.9 & & \\
Total & 38 & & &
\end{tabular}

Pair-wise comparisons

shoreline

$\begin{array}{cccc} & \text { Groups } & \boldsymbol{t} & \boldsymbol{p} \\ \text { LW, MW } & 1.6293 & \mathbf{0 . 0 0 7 5} \\ \text { transect } & \text { LW, HW } & 1.5994 & \mathbf{0 . 0 0 2 2} \\ & & 1.2758 & 0.0813 \\ & \text { T-I, T-II, } & 1.5253 & \mathbf{0 . 0 1 6} \\ \text { T-I, T-III } & 1.938 & \mathbf{0 . 0 0 1 3} \\ \text { T-I, T-IV } & 1.8044 & \mathbf{0 . 0 0 1} \\ \text { T-I, T-V } & 1.5463 & \mathbf{0 . 0 1 2 8} \\ \text { T-II, T-III } & 0.712 & 0.8867 \\ \text { T-II, T-IV } & 0.83582 & 0.758 \\ \text { T-II, T-V } & 0.85708 & 0.7046 \\ \text { T-III, T-IV } & 0.96906 & 0.5031 \\ \text { T-III, T-V } & 1.3094 & 0.0727 \\ \text { T-IV, T-V } & 1.175 & 0.1728 \\ \text { year } & & \\ \text { 2016, 2017 } & 1.731 & \mathbf{0 . 0 0 1 7} \\ \text { 2016, 2018 } & 1.7007 & \mathbf{0 . 0 0 0 7} \\ & & 0.9731 & 0.4756\end{array}$

LW, low shore; MW, mid shore; HW, upper shore; T, transect. Significant p-values are shown in bold. 
and T-IV (av 1.1 each) (Figure 3B). Pielou's evenness $J$ ' was high at all transects $(\geq 0.6)$. Univariate diversity indices with the exception of Pielou's evenness $J$ ' (one-way ANOVA, $F=4.44$; $p=0.004)$ were not significantly different between different transects (Figure 3).

The dominant amphipod species differed between transects (Figure 4). The relative densities of the two dominant species, M. grossimana and A. tenuicornis, were mostly accountable for dissimilarities between the transects (Supplementary 2B). The dissimilarity between T-I and T-II (AvD $=93.52 \%)$, T-I and T-III (AvD $=96.57 \%)$, T-I and T-IV (AvD = 91.84\%), and T-I and $\mathrm{T}-\mathrm{V}(\mathrm{AvD}=89.10 \%)$ were primarily due to A. tenuicornis. The major contributor for distinction between T-II and T-III $(\mathrm{AvD}=87.55 \%)$, T-II and T-IV $(\mathrm{AvD}=85.33 \%)$, T-III and T-IV $(\mathrm{AvD}=84.85 \%)$, T-III and T-V $(\mathrm{AvD}=89.05 \%)$, and T-IV and $\mathrm{T}-\mathrm{V}(\mathrm{AvD}=82.94 \%)$ was M. grossimana. Grandidierella sp. and M. grossimana were the species that majorly distinguished T-II and $\mathrm{T}-\mathrm{V}(\mathrm{AvD}=86.39 \%)$.

\section{Vertical Spatial Distribution}

Clear spatial vertical patterns in amphipod assemblage structure were evidenced. LW constituted $62.05 \%$ of the total amphipod abundance, whereas the MW and HW contributed 22.19 and $15.77 \%$ abundances, respectively (Table 3 ). The trend of decreasing amphipod density along the vertical gradient was consistently observed during all 3 years. Evidently, the LW recorded highest average amphipod abundance (939 ind $\mathrm{m}^{-2}$ ), followed by the MW (336 ind $\mathrm{m}^{-2}$ ) and the HW (239 ind $\mathrm{m}^{-2}$ ) (Figure 5A). Similarly, the highest species richness, $d$ (Margalef index); species evenness, $J$ ' (Pielou's), and Shannon-Weiner Index, $H^{\prime}\left(\log ^{2}\right)$ were recorded from the LW (Figures 5B-D). All the univariate measures varied significantly among shore levels (Figure 5). PERMANOVA analyses showed significant variation among shore levels (Pseudo-F $=3.38 ; p=0.002$ ) (Table 2). Pair-wise test indicated that the amphipod assemblages differed significantly between LW and MW $(t=1.6293, p=0.007)$ and between $\mathrm{LW}$ and $\mathrm{HW}(t=1.5994, p=0.002)$. However,

TABLE 3 | Species density, species number, and dominant amphipod taxa at different shorelines during various study years.

\begin{tabular}{|c|c|c|c|}
\hline Year & Lower & Middle & Upper \\
\hline \multicolumn{4}{|l|}{2016} \\
\hline Density range & $8-650$ ind $m^{-2}$ & $8-700$ ind $m^{-2}$ & $8-783$ ind $m^{-2}$ \\
\hline Total density & 3956 ind $m^{-2}$ & 2447 ind $m^{-2}$ & 1432 ind $m^{-2}$ \\
\hline Species number & 25 & 17 & 7 \\
\hline \multirow[t]{4}{*}{ Dominant taxa } & Lyssianasa ceratina (31.8\%) & Ampelisca typica (31.3\%) & Allomelita pellucida (54.7\%) \\
\hline & Maera grassimana (14.1\%) & Dexamine spinosa (17.7\%) & Grandidierella sp. (38.4\%) \\
\hline & Eriopisella sechellensis (10.7\%) & Ampelisca diadema (13.9\%) & \\
\hline & & Ampelisca eschrichtii (13.6\%) & \\
\hline \multicolumn{4}{|l|}{2017} \\
\hline Density range & $8-1092$ ind $m^{-2}$ & $8-208$ ind $m^{-2}$ & 8-233 ind $m^{-2}$ \\
\hline Total density & 6987 ind $\mathrm{m}^{-2}$ & 1339 ind $m^{-2}$ & 1130 ind $m^{-2}$ \\
\hline Species number & 34 & 16 & 16 \\
\hline \multirow[t]{4}{*}{ Dominant taxa } & Ampithoe ramondi (20.3\%) & Ampelisca tenuicornis (33.5\%) & Maera sp. (20.6\%) \\
\hline & Maera grassimana (17.5\%) & Grandidierella sp. (27.3\%) & Microprotopus sp. (16.2\%) \\
\hline & Eriopisella sechellensis (14.8\%) & & Maera grassimana (14.0\%) \\
\hline & Lyssianasa ceratina (11.2\%) & & Ampelisca tenuicornis (11.0\%) \\
\hline \multicolumn{4}{|l|}{2018} \\
\hline Density range & $6-631$ ind $m^{-2}$ & $6-338$ ind $m^{-2}$ & $6-575$ ind $m^{-2}$ \\
\hline Total density & 3145 ind $m^{-2}$ & 1252 ind $m^{-2}$ & 1018 ind $m^{-2}$ \\
\hline Species number & 20 & 18 & 6 \\
\hline \multirow[t]{4}{*}{ Dominant taxa } & Maera grassimana (24.9\%) & Eriopisella sechellensiss (34.0\%) & Eriopisella sechellensis (56.4\%) \\
\hline & Ampelisca tenuicornis (15.9\%) & Grandidierella sp. (25.0\%) & Parhyale hawaiensis (33.1\%) \\
\hline & Lysianasa ceratina (12.3\%) & Maera grassimana (19.5\%) & \\
\hline & Dexamine spinosa (11.6\%) & & \\
\hline \multicolumn{4}{|l|}{ Overall } \\
\hline Total density & 14,088 ind $m^{-2}$ & 5,038 ind $m^{-2}$ & 3,580 ind $m^{-2}$ \\
\hline Total species number & 56 & 39 & 25 \\
\hline \multirow[t]{3}{*}{ Dominant families } & Lysianassidae (25.2\%) & Dexaminidae (21.7\%) & Melitidae (30.3\%) \\
\hline & Eriopisidae (17.4\%) & Eriopisidae (21.3\%) & Eriopisidae (23.2\%) \\
\hline & Maeridae (15.9\%) & Ampeliscidae (20.9\%) & Aoridae (11.0\%) \\
\hline \multirow[t]{4}{*}{ Dominant taxa } & Maera grassimana (18.2\%) & Ampelisca typica (15.9\%) & Allomelita pellucida (21.9\%) \\
\hline & Lysianasa ceratina (17.2\%) & Grandidierella sp. (13.5\%) & Eriopisella sechellensis (16.0\%) \\
\hline & Ampithoe ramondi (12.9\%) & Ampelisca tenuicornis (11.2\%) & Grandidierella sp. (15.3\%) \\
\hline & Eriopisella sechellensis (12.1\%) & Eriopisella sechellensiss (10.2\%) & Parhyale hawaiensis (11.0\%) \\
\hline
\end{tabular}



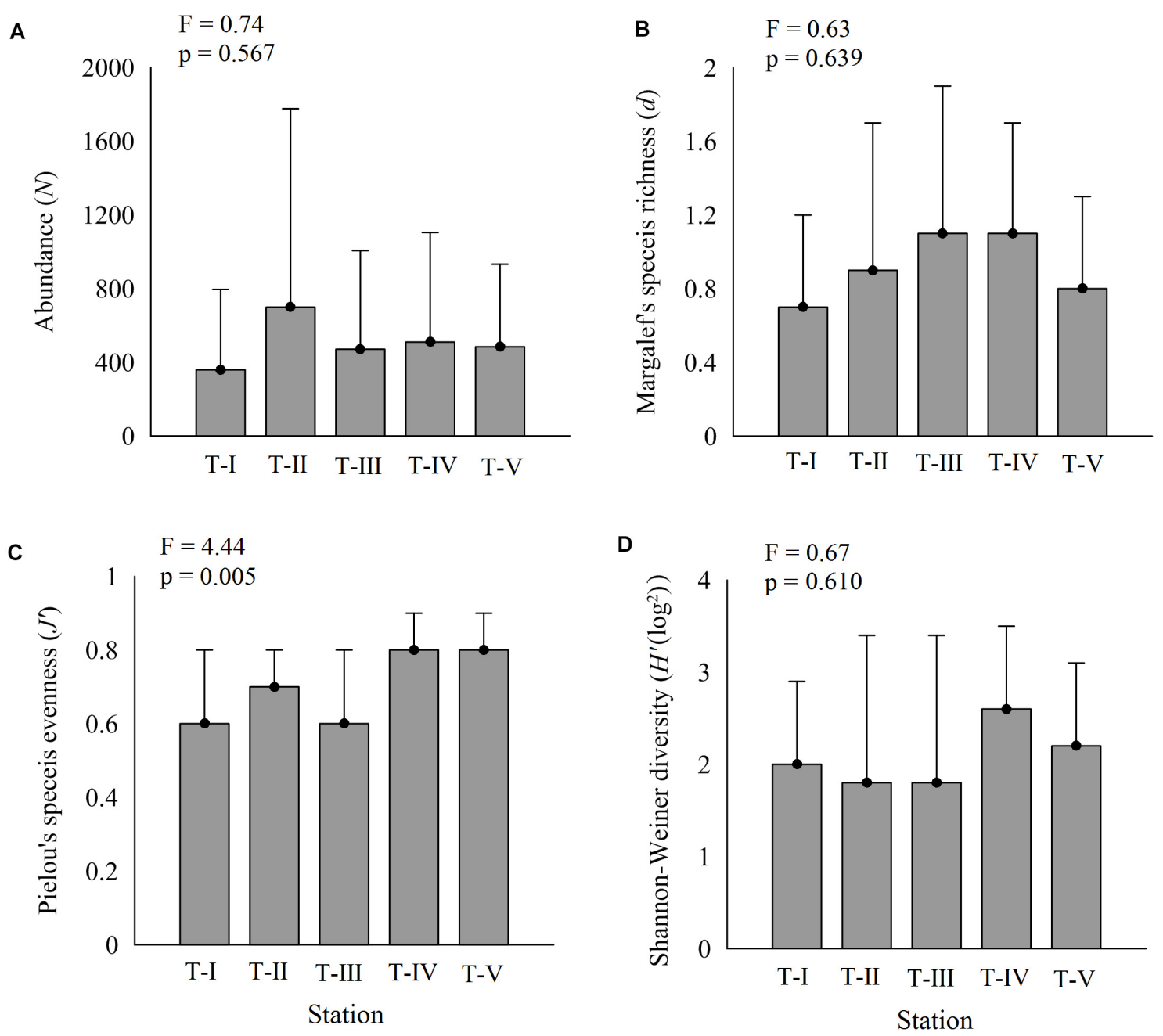

FIGURE 3 | Variations in amphipod diversity indices (avg \pm SD) along five transects. (A) Amphipod abundance, (B) $d$-species richness, (C) J'-Pielou's evenness, and (D) $H^{\prime}$-Shannon-Wiener index.

this differentiation was not significant between MW and HW (Table 2). Ordination of amphipod assemblage structure exposed grouping patterns among different shore levels (Figure 6). The LW stations of all transects except T-I were clustered together indicating similarity of amphipod species composition. The LW stations of T-I had a different species composition from that of other four transects. Some HW stations were grouped with MW which confirmed the results of pair wise PERMANOVA analyses. The dissimilarities between different shorelines were mainly due to differences in relative densities of $M$. grossimana, Dexamine spinosa, L. ceratina, A. ramondi, E. sechellensis (more abundant in LW), A. tenuicornis, Grandidierella sp., Ampelisca typica (more abundant in MW) (Supplementary 2C).

The dominant amphipod species composition varied significantly between shore levels during all 3 years (Table 3 ). The LW displayed consistently high values of $J^{\prime}(\geq 0.6 \pm 0.2)$ and $H^{\prime}(\geq 2.0 \pm 0.5)$. The LW of T-II had the maximum amphipod abundance and that of T-V recorded the lowest. The LW of T-I recorded lower $d, J^{\prime}$, and $H^{\prime}$ values as compared to other transects
(Supplementary 4). Contrastingly, highest $d$ and $H^{\prime}$ values were recorded at T-I in MW. Mostly balanced amphipod assemblages were present at the MW $\left(J^{\prime}=0.5 \pm 0.2\right.$ to $\left.0.8 \pm 0.2\right)$. Among the transects, highest abundance of amphipods was recorded at MW of T-I. The HW of T-V registered maximum $N$ and $H$ ', whereas the HW of T-IV displayed highest $d$ values. At HW, amphipods were close to nil at T-II and completely absent at T-III during all three study periods (Figure 2 and Supplementary 4). At rest of the transects, the $\mathrm{HW}$ indicated evenness $\left(J^{\prime}\right)$ of $\geq 0.5$.

\section{Biological Trait Analysis}

The first two axes of the FCA performed on the "traits-by-station" matrix accounted for $54 \%$ of the total variability of which $33 \%$ was explained by FC1 and $21 \%$ by FC2 (Figure 7). The correlation ratios $(>10 \%)$ indicated that the traits habitat, mobility, and body size were more separated on FC1, whereas the FC2 was associated with the trait bioturbation. Feeding mode was correlated with both axes (Table 4). 


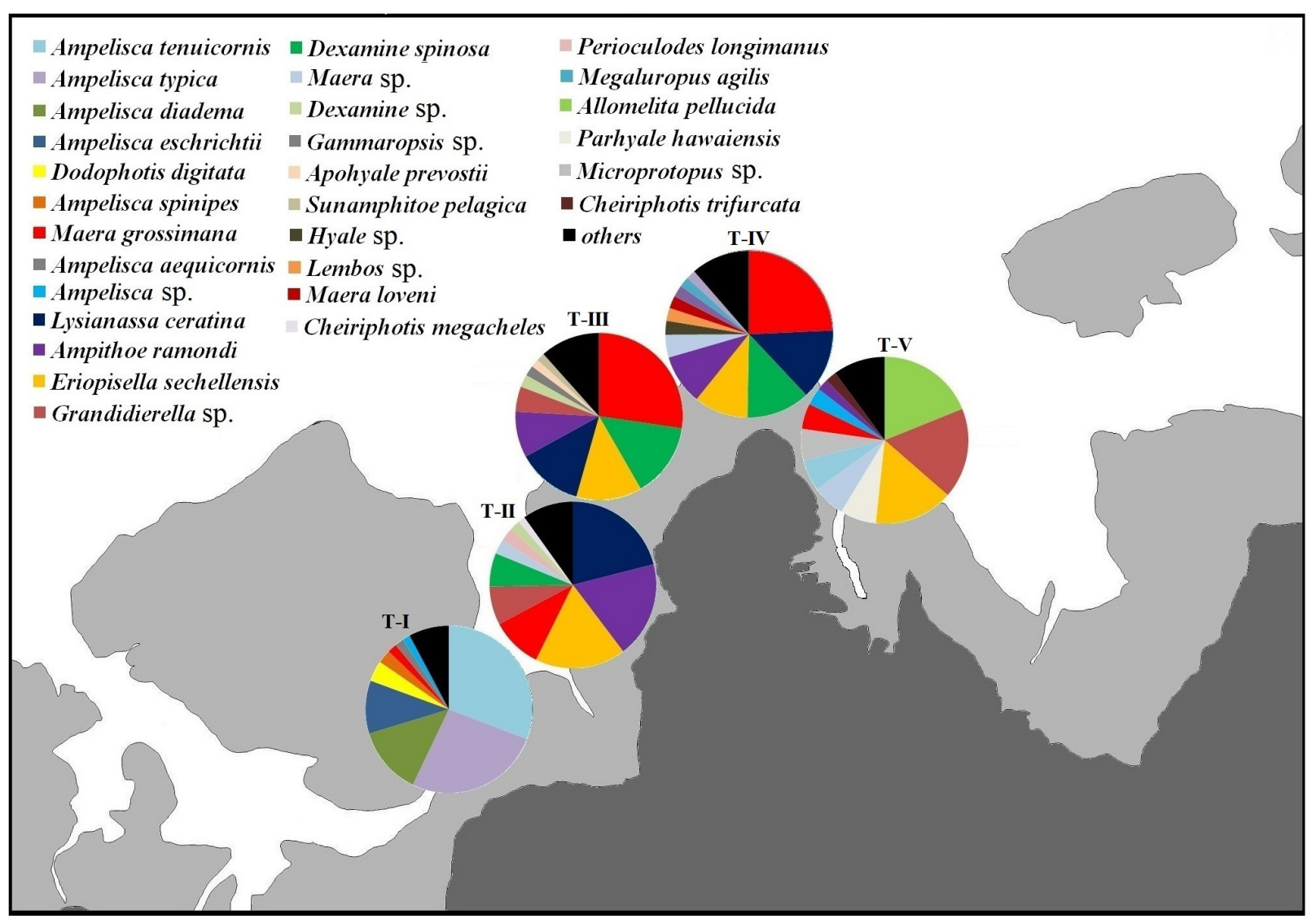

FIGURE 4 | Relative abundances of dominant amphipod species (averaged across different shore levels and years) composition at different transects.

The FCA plot (Figures 7, 8) clearly portrayed the association of the LW stations of T-II, T-III, T-IV, and T-V with small to medium sized amphipod species with the following traits; epifauna, biodiffusers, motile, subsurface deposit feeders, browsers, scavengers, and burrowers. All HW and MW (except T-IV MW) stations and T-I LW were populated by very small sized amphipods with functional traits such as discretely motile, surface modifiers, predators, grazers, detritivores, suspension feeders, tube building, and free living (Figures 7, 8). The highest FD index was recorded at T-IV LW $(3.1 \pm 0.1)$, whereas no FD index values were derived at T-II HW and T-III HW due poor representation or absence of amphipods. T-II LW (2.7 \pm 0.7$)$, T-III LW (2.7 \pm 0.5$)$, and T-V LW (2.5 \pm 0.7$)$ had comparable FD values (Figure 9). Except at T-I, all LW stations had higher FD than other stations. FD decreased along the spatial vertical gradient from LW to HW.

\section{DISCUSSION}

The GoK MNPS harbors some of the most biodiverse and sensitive coralline ecosystems of the Indian subcontinent (Subba Rao and Sastry, 2005). This is the first quantitative study on diversity and functionality of amphipod assemblages in the intertidal habitats of the GoK MNPS, providing valuable baseline for future ecological investigations. An earlier compilation of intertidal amphipods by Surya Rao (1972) recorded 132 species of gammaridean amphipods belonging to 24 families from various intertidal regions along the Indian coast. A total of 17 amphipod species were recorded at Krusadai Islands, an MPA in the Gulf of Mannar (Gravely, 1927; Raj, 1927). Amphipoda contributed to less than $3 \%$ of macrobenthic density in the sandy beaches of Lakshadweep, another MPA in the Arabian Sea (Rivonker and Sangodkar, 1997); 117 amphipod species belonging to 33 families were reported from 50 sampling sites of the Alacranes Reef National Park, Gulf of Mexico (PazRíos et al., 2019). A study conducted on temporal distributions of amphipod species from the Mexican Caribbean reef Banco Chinchorro revealed 26 amphipod species represented by 16 families and 24 genera (Oliva-Rivera, 2003). In this study, 71 amphipod species belonging to 23 families were recorded from the five intertidal transects of GoK, signifying the exceptional amphipod diversity of this MPA. These results clearly indicated that the intertidal regions particularly coralline types are favorable habitats for diverse amphipod species (Surya Rao, 1972; Narayanan and Sivadas, 1986).

The amphipod species were well distributed at different transects, though in varying proportions. For example, 
A

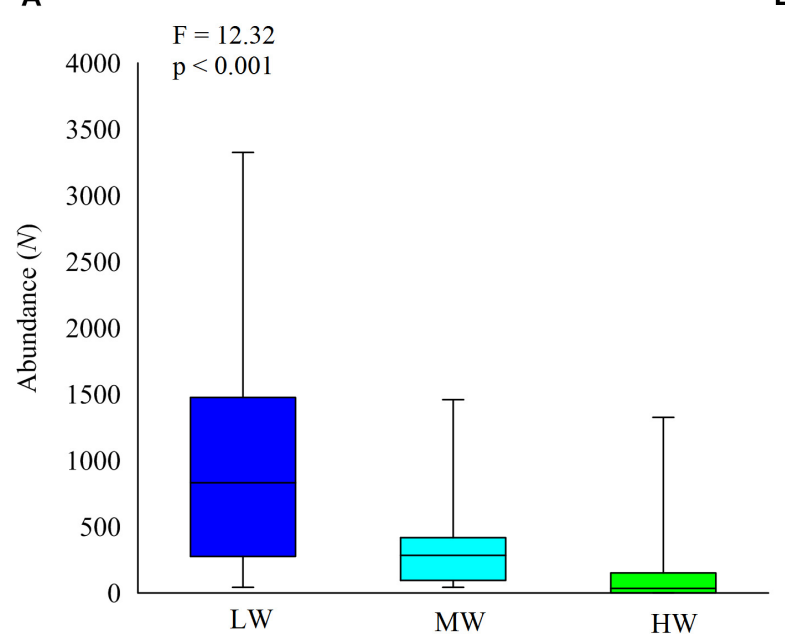

C

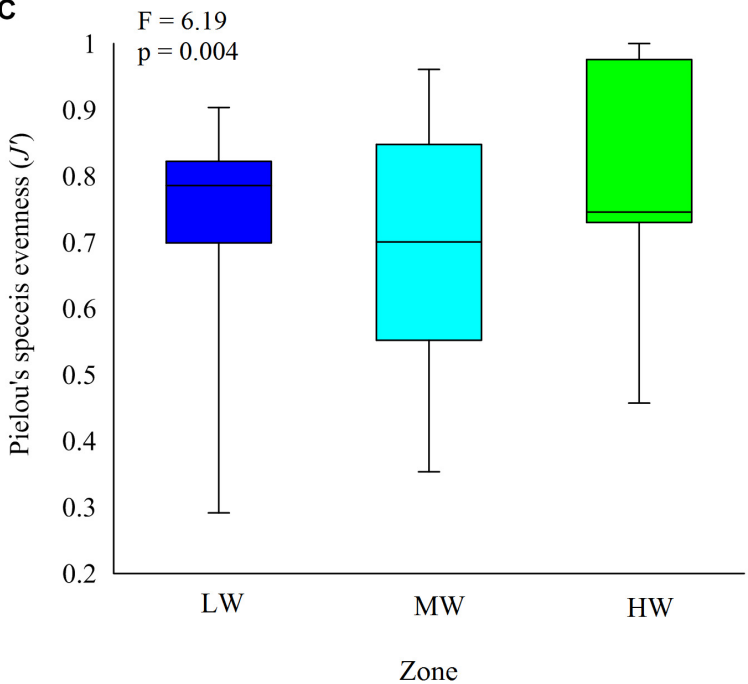

B

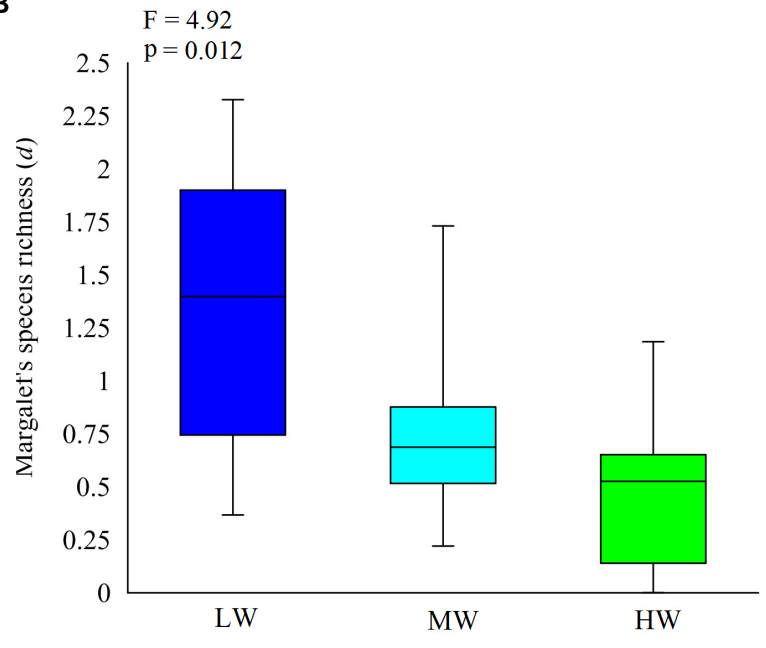

D

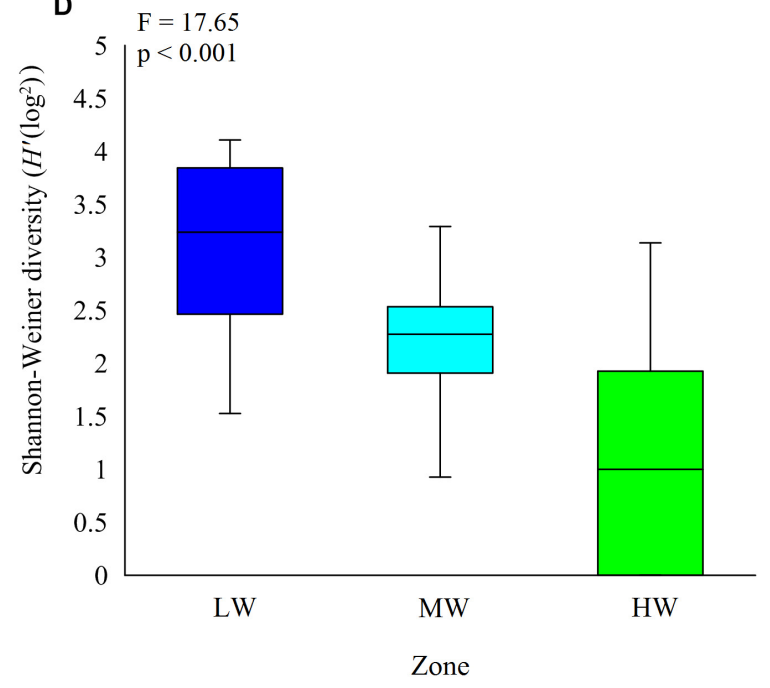

FIGURE 5 | Shore level variation in amphipod species. (A) abundance, (B) Margalef's species richness, (C) Pielou's species evenness, and (D) Shanon-Weiner diversity. LW, low shore; MW, mid shore; HW, upper shore. Middle horizontal lines represent the mean.

M. grossimana comprised $27.3 \%$ at T-III whereas at other transects the composition of $M$. grossimana varied from 1.8 to $24.3 \%$ (Supplementary 1). The intertidal zone of T-I was predominantly constituted by fine sediments (Sinha, 1997; National Institute of Oceanography [NIO], 2018) and was populated chiefly by the Ampeliscidae (75.1\%). The proportion of ampeliscids were very high at T-I as compared to other transects and was one of the major contributors to the significant spatial differences between the Kalubhar transect and the other four. The ampeliscids are known to have an affinity for finer sediments (Parker, 1984; Marques and BellanSantini, 1991). The dominant species at T-I, A. tenuicornis and A. typica are also reported to be abundant in silty sediments (Mills, 1967; Sheader, 1977; Lourido et al., 2008). While the type of substratum probably influenced the significant difference in amphipod assemblage structure between T-I and others, it was also possible that the different sampling methods employed at this location may have contributed to the variance.

Sharp vertical patterns were apparent in the amphipod assemblage structure in the coralline intertidal areas investigated. The differential abiotic stress known to occur at different shore levels could have influenced the vertical differences observed in the amphipod assemblage structure (Menge and Branch, 2001; Valdivia et al., 2011). Studies have suggested that the vertical gradient of environmental stress occurring along the intertidal habitats influences the intensity of interspecific interactions and governs the variations in community structure (Paine, 1974; Benedetti-Cecchi et al., 1999; Díaz and McQuaid, 2011). Analyses of individual amphipod species distributions along the different transects indicated that the distribution of majority of species was restricted to particular levels on the shore that were best suited for their survival. Thus, the species Apohyale prevostii, 


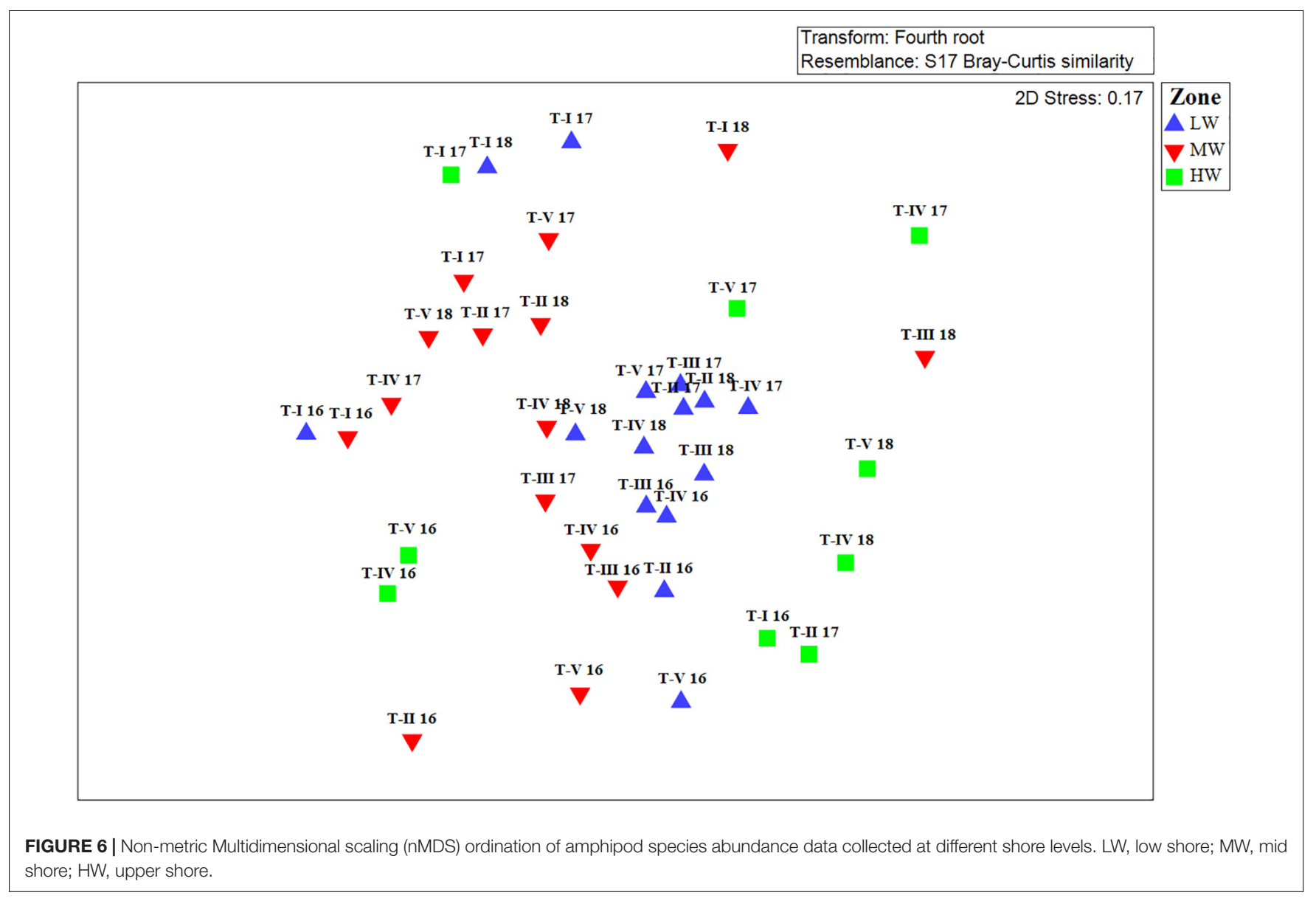

Cyproidea ornata, Idunella chilkensis, Megaluropus agilis, Metaphoxus simplex, Paradeutella bidentata, Parelasmopus suensis, and Perionotus alaniphilas were observed only at LW, Ampelisca eschrichtii, Ampelisca gibba, Paracaprella sp., Peramphithoe sp., and Photis reinhardii at MW and Monoculodes sp., Parhyale hawaiensis, and Urothoe brevicornis were observed only at HW demonstrating sharp zone specific distributions. Studies have attributed such species distributional patterns at different intertidal zones to diverse physiological requirements in relation to physical stress and various biological relationships (Underwood, 1981; Araújo et al., 2005; Pandey and Thiruchitrambalam, 2018).

The co-existence of a mosaic of amphipod species at low water levels of various transects was also notable. For instance, at T-III and T-IV, the dominant species M. grossimana (21$34 \%$ ) coexisted with another co-dominant species, L. ceratina $(14-17 \%)$ at LW. At T-II LW, high percentages of L. ceratina (21\%) and A. ramondi (20\%) were observed. At T-I, the species A. tenuicornis (59\%) and A. typica (15\%) together constituted majority of the amphipod population. This kind of mosaic relationship is an important characteristic of intertidal organisms particularly at low shore level (Menge et al., 1993; Araújo et al., 2005). Araújo et al. (2005) observed similar mosaic assemblages from the intertidal rocky shores in the northwest coast of Portugal.
The most diverse amphipod species were observed from the LW areas of all transects of Narara. Most of the peracarid crustaceans especially amphipods prefer areas optimal for their survival such as the low shore areas. These areas are exposed to shorter durations of air exposure and reduced wave action than middle and upper zones (Bueno et al., 2017). In addition, biological factors such as increased food availability and shelter options (host preferences) also make the lower shore a more conducive habitat for the survival of diverse amphipod species (Chavanich and Wilson, 2000). Algae have been identified as a major variable determining the distribution patterns of amphipods in various intertidal habitats (Bueno et al., 2016, 2017, 2019). Hacker and Steneck (1990) suggested that amphipods favored algae with complex morphology to protect them from predators. The common vagile amphipod species such as M. grossimana, L. ceratina, and A. ramondi were present in large numbers at LW, with incrementally reduced densities at MW and HW. These amphipods prefer to reside in algal holdfast and algal tufts mainly to obtain food and using them as hiding places (Penrith and Kensley, 1970; Brawley and Adey, 1981; Duffy and Hay, 2000; Gallmetzer et al., 2005). The lower intertidal shores of Narara reef have been reported to sustain an average algal cover of $89 \%$ comprising of 31 species and dominated by Chlorophyta (71.18\%) (Roy et al., 2015). The seaweed, Ulva lactuca (Family: Chlorophyceae) 


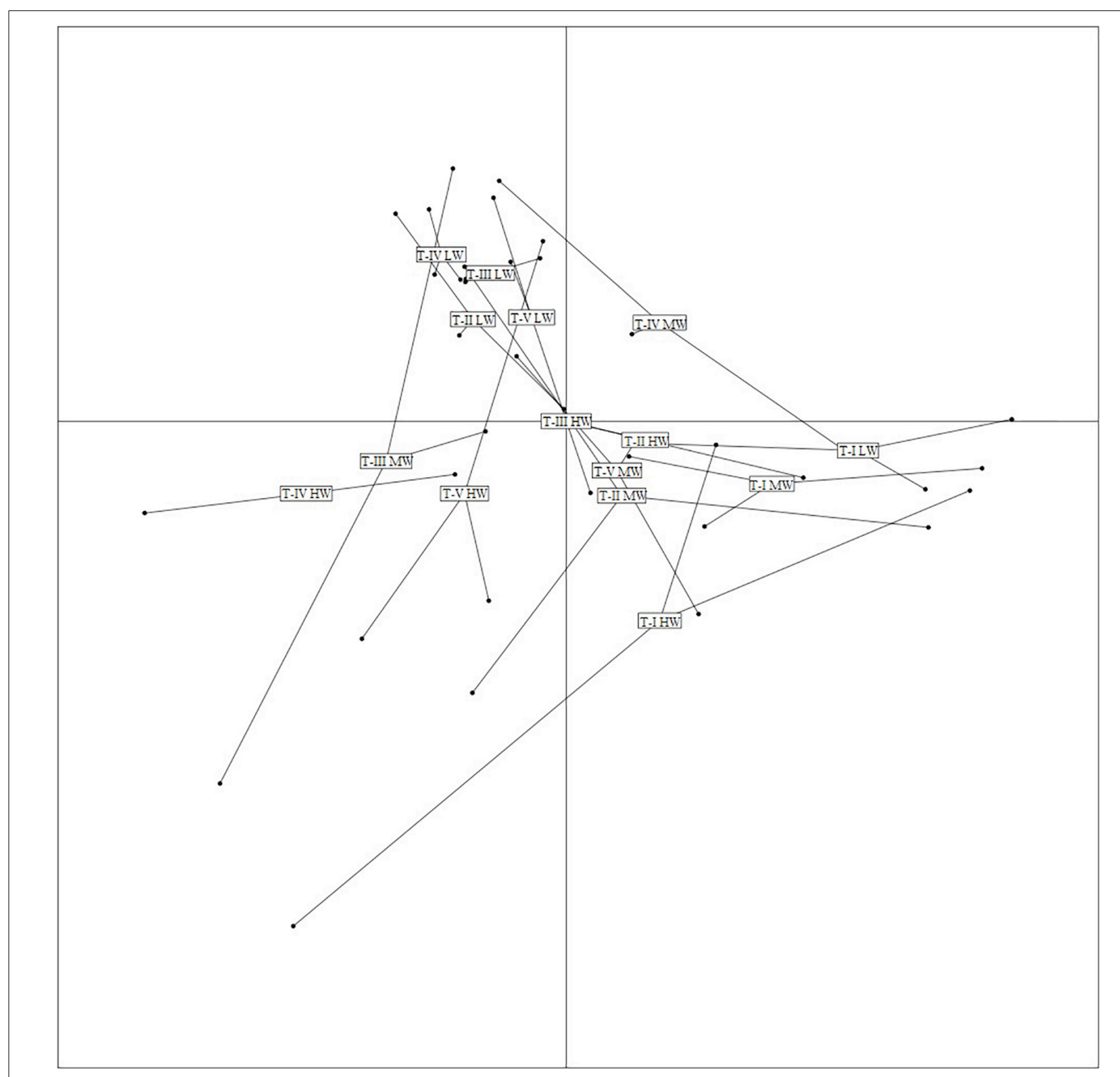

FIGURE 7 | Result of Fuzzy correspondence analysis (FCA) along the first two axes. Ordination of samples based on trait-modalities weighted by amphipod species abundances at various transects during all three study periods. LW, low shore; MW, mid shore; HW, upper shore.

was observed to be the most dominant species in the study area during all the seasons (Adhavan et al., 2015). Ulva is known to be a significant food sources for many amphipod species from the different habitats (Sfriso and Marcomini, 1997; Balducci et al., 2001; Zheng et al., 2014). Amphipods are reported to be the major occupants of Ulva dominated algal beds (Balducci et al., 2001; Zheng et al., 2014). Therefore, it is surmised that the availability of copious food sources probably helped establish diverse and abundant amphipod assemblages in the low intertidal zones of the study region. In addition to U. lactuca, Sargassum cinereum, Sargassum tenerrimum,
Padina boryana, Padina boergesenii (Phaeophyta), Caulerpa racemosa, Caulerpa taxifolia, Ulva fasciata, Ulva reticulate (Chlorophyta), Acanthophora dendroides, Gracilaria corticata, Gracilaria verrucosa, Scinaia monoliformis (Rhodophyta) were also found in good numbers at the LW of the Narara transects (Adhavan et al., 2015; Roy et al., 2015). The distinct spatial vertical patterns of amphipod assemblages followed the general model described by Menge and Sutherland (1987). The upper limit of intertidal amphipods was probably set by the inherent physiological ability of species to survive the harsh conditions of prolonged exposure, whereas the lower limit may be determined 


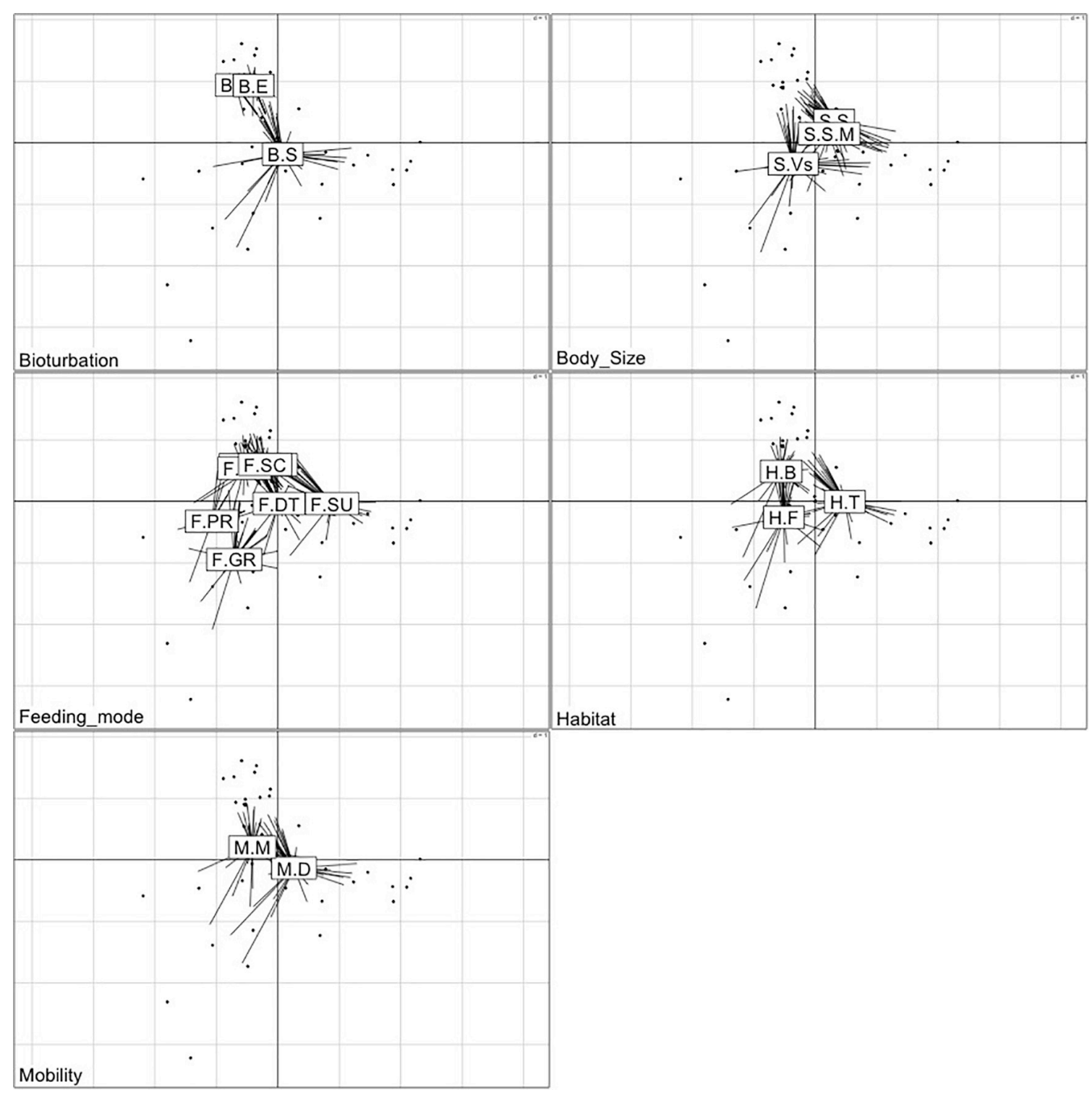

FIGURE 8 | Two-dimensional plots of the functional traits with corresponding modalities based on Fuzzy correspondence analysis (FCA) of the abundance-weighted amphipod assemblage traits. The labels of the modalities within each trait category are provided in Table 1.

by the outcome of inter-specific interactions (Chavanich and Wilson, 2000; Bueno et al., 2016).

Previous comparisons between functional and taxonomical composition of natural communities have yielded disparate results, varying from strong to weak congruence between these two dimensions (Cochrane et al., 2012; Frid and Caswell, 2015; Kokarev et al., 2017). This study investigated amphipod FD patterns with reference to the taxonomic diversity patterns in the GoK MNPS. Most amphipod species are mobile in intertidal habitats with relatively high swimming abilities, so they can freely move between the areas rich in food and also to protect them from predation (Jażdżewska and Siciński, 2017). In the current study, mobile epifaunal amphipod abundances were observed to be higher at the LW of the all intertidal transects except T-I. Generally, the increased risk of predation makes more mobile species prevalent at LW (Paine, 1969; Underwood, 2000). Amphipod species roam during night in search of freshly deposited food in the absence of predators, whereas in the presence of predators, the amphipod species find secure places to avoid the predation (Gestoso et al., 2014). In particular, the animals with reduced mobility face increased predation risk at LW zones (Underwood, 2000). Mobility is an important mechanism that reduces competition by allowing co-existence of competing species through avoidance of predators and adverse microclimate conditions (McBane and Croker, 1983).

In the present study, amphipods with burrowing behavior were observed more abundantly at LW. The lysianassid and ampithoid amphipods that occurred in high abundances at 

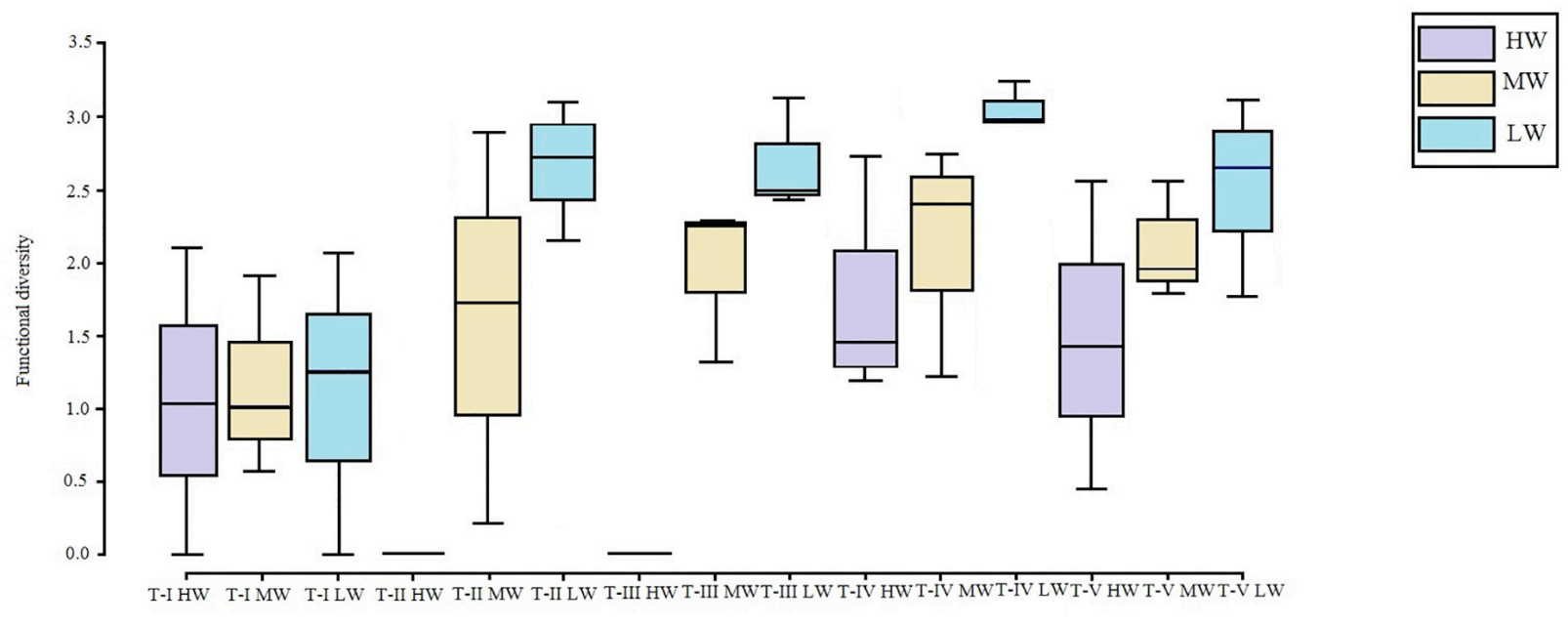

FIGURE 9 | Box plots of functional diversity (FD) (avg \pm SD) based on amphipod abundance at all the sampling sites. LW, low shore; MW, mid shore; HW, upper shore.

TABLE 4 | Correlation matrix between the first two axes of the FCA (Fuzzy correspondence analysis) and the functional traits studied.

\begin{tabular}{lcc}
\hline Functional Traits & FC $\mathbf{1}$ (33\%) & FC 2 (21\%) \\
\hline Feeding mode & $\mathbf{0 . 3 8}$ & $\mathbf{0 . 2 3}$ \\
Habitat & $\mathbf{0 . 2 5}$ & 0.06 \\
Mobility & $\mathbf{0 . 1 1}$ & 0.03 \\
Body size & $\mathbf{0 . 1 0}$ & 0.09 \\
Bioturbation & 0.03 & $\mathbf{0 . 1 7}$ \\
\hline
\end{tabular}

Figures in brackets indicate the variation explained by the corresponding axis. Higher contributions are highlighted in bold.

LW are known to construct burrows in holdfast and stripes of large macroalgae to get aid in reproduction, guaranteed access to food and shelter against predators (Mejaes et al., 2015). Contrary to this, the less mobile and tube dwelling amphipod taxa were present mostly at MW and HW. Tube construction protects the amphipods from strong waves and high temperatures that frequently occur at upper shore (Carter, 1982). During tube construction, amphipods transport particles and fluids which influence the physical and chemical processes in the surface sediments (Rhoads, 1974; Aller, 1988; Kristensen, 1988). Bioturbation is reported to be strongly related to the organism's trophic diversity, mobility, and resident habitats (Dauwe et al., 1998; Pearson, 2001). This was evidenced in our study as surface modifiers were more abundant at the MW and HW and were associated with the tube building and discretely motile traits. Conversely, the epifaunal and bio diffuser functional traits were mostly linked with mobile and burrowing traits at LW (Figure 8). Benthic amphipods use diverse food sources within their microhabitats and therefore their trophic diversity is widely used in many ecological studies (Guerra-García et al., 2014). The great variety of feeding mechanisms observed in the amphipods substantiated that the study area provided ample and multiple food sources. More feeding types were observed at the heterogeneous LW, whereas the MW and HW regions sustained lesser trophic diversity. These observations concur with GuerraGarcía and Tierno de Figueroa (2009) and Vázquez-Luis et al. (2012) who highlighted that the diet of amphipods was more diverse in algal and seagrass habitats than those composed only of bed sediments.

Several hypotheses have been put forward to explain the shore level gradient in body size observed at different intertidal habitats. Olsgard et al. (2008) suggested that the habitats with low stress environmental conditions can sustain large body sized organisms. In the present investigation, bigger amphipods were observed in the low intertidal shore except at T-I. Underwood (2000) opined that the general increase in size gradient of intertidal organisms at low shore levels was due to the lower predation rates of large sized animals. In general, the large animals wandering at low shore will tend to stay there, while the small body sized organisms will continue moving upward. Despite the food available at low shores, the enhanced risk of predation makes the smaller animals move toward upper shore (Paine, 1969; Underwood, 2000). The large body sized organisms survive at low shore due to lower predation rates. Also, the small body size helps to retain more amount of water and the absorbent nature of the amphipod tubes in upper shore helps the organism to tolerate the desiccation from exposure (Carter, 1982). Hacker and Steneck (1990) suggested that amphipod species choose habitats based on body-size scaling in an attempt to avoid predation and desiccation. In the present study, it was evident that the spatial component of habitat architecture was an important criterion in size-dependent habitat selection of benthic amphipods in intertidal regions.

Functional diversity trends also suggested that except at T-I, LW had more functional groups, whereas HW had functionally less diverse amphipod assemblages. At T-I, FD was low at all zones. Moreover, amphipod FD indices mirrored the taxonomic diversity patterns indicating strong inter-correlated changes 
along transects and zones. Functional traits can be used to index the ecological functioning of assemblages and one might expect large scale changes in taxonomic composition to result in changes in trait composition and hence ecological functioning (Frid and Caswell, 2015). The relative variance in functional trait composition between zones as observed in this study concurs with the environmental filtering and habitat template concepts, wherein the structure and environmental conditions determine the community assembly through selection of certain species function traits (Pacheco et al., 2011). The strong congruence between the two dimensions of community suggested that the amphipod assemblage structure and functioning in the study area were probably influenced by the same complex of biotic or abiotic parameters.

Present results clearly indicated that vertical variations in amphipod assemblage structure were more distinct than horizontal variations measured at fine spatial scale. These results are consistent with other studies of rocky shores that have indicated large differences in the structure of assemblages from the upper to lower shore (Chavanich and Wilson, 2000; Menge and Branch, 2001; Valdivia et al., 2011). Of late, the horizontal and vertical variations in intertidal communities are being evaluated as a step to classify provenance of dissimilarity. For instance, Valdivia et al. (2011) identified that vertical biological variation in intertidal habitats was higher than horizontal variation measured at local scales, but lower than horizontal variation measured at regional scales. Catalán et al. (2020) reported that horizontal variation in community structure measured from local to regional scales never surpassed vertical variations. Many physical and biological factors are currently invoked to explain these horizontal and vertical zonation patterns of intertidal communities, but their effects are often difficult to evaluate. These studies have offered the observational background for experimental analyses on causal processes, including inter specific competition, predatory effects, physical factors, and the interplay between biological and physical processes (Benedetti-Cecchi, 2001). Although in the present study we have not investigated the causal processes explicitly, the functional trait patterns of amphipod assemblages described here may provide some clues on causes of vertical and horizontal variations of amphipod assemblages in the study region.

\section{CONCLUSION}

In this study, the taxonomic and FD patterns of amphipod assemblages in the coralline intertidal zones of GoK MNPS were documented. Pronounced differences were observed in amphipod assemblage structure and functional trait matrices along the horizontal and vertical gradients on the shore. Amphipods showed clear demarcation of spatial vertical zones with higher species diversity and functional trait composition being observed at the low shore levels which sustained structurally complex habitats. Different mosaic of amphipod species assemblages was observed at particular intertidal zones. Vertical variations in amphipod assemblage structure at different shorelines were higher than horizontal variations. Assigning biological traits to amphipod species provided additional insights to those from traditional taxonomic analyses. Patterns of species diversity distribution in the study area were mirrored by the functional traits. Understanding the diversity-function relationships of major faunal groups in sensitive ecosystems such as MPAs is important to understand the multiple ecological services rendered and to predict loss of ecological functions due to potential species loss. Detailed studies focusing on species specific functional characteristics of amphipods and the complex factors influencing the zonation patterns in future will provide a stronger scientific basis for marine ecosystem conservation strategies.

\section{DATA AVAILABILITY STATEMENT}

The raw data supporting the conclusions of this article will be made available by the authors, without undue reservation.

\section{AUTHOR CONTRIBUTIONS}

TS and SS contributed to the conception, design, and execution of the study and analyzed the data. SN and KR contributed to the software programming and data analysis. TS wrote the first draft of the manuscript. All authors contributed to manuscript revision and read and approved the submitted version.

\section{FUNDING}

This research did not receive any specific grant from funding agencies in the public, commercial, or not-for-profit sectors.

\section{ACKNOWLEDGMENTS}

The authors express their sincere thanks to Director CSIRNational Institute of Oceanography, India, for extending facilities. The authors express their special thanks to all team members from CSIR-NIO Mumbai Regional Centre, who helped during the field work. The invaluable help of Dr. Rakesh P. S. is gratefully acknowledged.

\section{SUPPLEMENTARY MATERIAL}

The Supplementary Material for this article can be found online at: https://www.frontiersin.org/articles/10.3389/fmars. 2020.589195/full\#supplementary-material 


\section{REFERENCES}

Adhavan, D., Kamboj, R. D., Chavdaand, D. V., and Bhalodi, M. M. (2014). Status of intertidal biodiversity of Narara Reef Marine National Park, Gulf of Kachchh, Gujarat. J. Mar. Biol Oceanogr. 3:2. doi: 10.4172/2324-8661.1000132

Adhavan, D., Marimuthu, N., Tikadar, S., and Sivakumar, K. (2015). Impact of algal bloom on mangrove and coral reef ecosystem in the Marine National Park, Gulf of Kachchh, Gujarat, India. J. Mar. Biol. Aquacult. 1, 1-2. doi: 10.15436/23810750.15 .006

Aller, R. C. (1988). "Benthic fauna and biogeochemical processes in marine sediments: the role of burrow structures," in Nitrogen Cycling in Coastal Marine Environments (SCOPE), eds T. H. Blackburn and J. Sørensen (Chichester: Wiley Press Inc), 301-338.

Anderson, M. J., Gorley, R. N., and Clarke, K. R. (2008). PERMANOVA for PRIMER: Guide to Software and Statistical Methods. Plymouth: PRIMER-E.

Araújo, R., Bárbara, I., Sousa-Pinto, I., and Quintino, V. (2005). Spatial variability of intertidal rocky shore assemblages in the northwest coast of Portugal. Estuar. Coast Shelf Sci. 64, 658-670. doi: 10.1016/j.ecss.2005.03.020

Balducci, C., Sfriso, A., and Pavoni, B. (2001). Macrofauna impact on Ulva rigida C. Ag. production and relationship with environmental variables in the lagoon of Venice. Mar. Environ. Res. 52, 27-49. doi: 10.1016/S0141-1136(00)00259-2

Barnard, J. L. (1979). Littoral gammaridean Amphipoda from the Gulf of California and the Galapagos Islands. Smithson. Contr. Zool. 271:149.

Bellwood, D. R., Hoey, A. S., and Choat, J. H. (2003). Limited functional redundancy in high diversity systems: resilience and ecosystem function on coral reefs. Ecol. Lett. 6, 281-285. doi: 10.1046/j.1461-0248.2003.00432.x

Benedetti-Cecchi, L. (2001). Variability in abundance of algae and invertebrates at different spatial scales on rocky sea shores. Mar. Ecol. Prog. Ser. 215, 79-92. doi: $10.3354 /$ meps 215079

Benedetti-Cecchi, L., Menconi, M., and Cinelli, F. (1999). Pre-emption of the substratum and the maintenance of spatial pattern on a rocky shore in the northwest Mediterranean. Mar. Ecol. Prog. Ser. 181, 13-23. doi: 10.3354/ meps 181013

Blanchette, C. A., Melissa Miner, C., Raimondi, P. T., Lohse, D., Heady, K. E., and Broitman, B. R. (2008). Biogeographical patterns of rocky intertidal communities along the Pacific coast of North America. J. Biogeog. 35, 1593-1607. doi: 10.1111/j.1365-2699.2008.019 13.x

Brawley, S. H., and Adey, W. H. (1981). The effect of micrograzers on algal community structure in a coral reef microcosm. Mar. Biol. 61, 167-177. doi: 10.1007/BF00386656

Bremner, J. (2005). Assessing Ecological Functioning in Marine Benthic Communities. Doctoral dissertation. Newcastle upon Tyne: University of Newcastle upon Tyne.

Bremner, J. (2008). Species' traits and ecological functioning in marine conservation and management. J. Exp. Mar. Biol. Ecol. 366, 37-47. doi: 10.1016/ j.jembe.2008.07.007

Bremner, J., Rogers, S. I., and Frid, C. L. J. (2006). Matching biological traits to environmental conditions in marine benthic ecosystems. J. Mar. Syst. 60, 302-316. doi: 10.1016/j.jmarsys.2006.02.004

Brown, A. C., and McLachlan, A. (1990). Ecology of Sandy Shores. Amsterdam: Elsevier Press.

Bueno, M., Dias, G. M., and Leite, F. P. (2017). The importance of shore height and host identity for amphipod assemblages. Mar. Biol. Res. 13, 870-877. doi: $10.1080 / 17451000.2017 .1306650$

Bueno, M., Flores, A. A. V., and Leite, F. P. P. (2019). Seasonal dynamics of amphipod assemblages in intertidal coralline algal mats on two Brazilian shores. Bull. Mar. Sci. 95, 83-99. doi: 10.5343/bms.2018.0028

Bueno, M., Tanaka, M. O., Flores, A. A. V., and Leite, F. P. P. (2016). Vertical differences in species turnover and diversity of amphipod assemblages associated with coralline mats. Estuar. Coast Shelf Sci. 181, 153-159. doi: 10. 1016/j.ecss.2016.08.037

Carter, J. W. (1982). Natural history observations on the gastropod shell-using amphipod Photis conchicola Alderman, 1936. J. Crustacean Biol. 2, 328-341. doi: $10.2307 / 1548051$

Catalán, A. M., Valdivia, N., and Scrosati, R. A. (2020). Interhemispheric comparison of scale-dependent spatial variation in the structure of intertidal rocky-shore communities. Ecosphere 11:e03068. doi: 10.1002/ecs2.3068
Chavanich, S., and Wilson, K. A. (2000). Rocky intertidal zonation of gammaridean amphipods in Long Island Sound. Connecticut. Crustaceana 73, 835-846. doi: $10.1163 / 156854000504840$

Chevenet, F., Dolédec, S., and Chessel, D. (1994). A fuzzy coding approach for the analysis of long-term ecological data. Freshw. Biol. 31, 295-309. doi: 10.1111/j. 1365-2427.1994.tb01742.x

Clarke, K. R., and Gorley, R. N. (2015). PRIMER v7: User Manual/Tutorial, 3rd Edn. Plymouth: Primer-E Ltd.

Cochrane, S. K., Pearson, T. H., Greenacre, M., Costelloe, J., Ellingsen, I. H., Dahle, S., et al. (2012). Benthic fauna and functional traits along a polar front transect in the barents sea-advancing tools for ecosystemscale assessments. J. Mar. Syst. 94, 204-217. doi: 10.1016/j.jmarsys.2011. 12.001

Conlan, K. E. (1994). Amphipod crustaceans and environmental disturbance: a review. J. Nat. His. 28, 519-554. doi: 10.1080/00222939400770241

Conradi, M., and Cervera, L. (1995). Variability in trophic dominance of amphipods associated with the bryozoan Bugula neritina (L., 1758) in Algeciras Bay (Southern Iberian Peninsula). Pol. Arch. Hydrobiol. 42, 483-494.

Dauwe, B. P. H. J., Herman, P. M. J., and Heip, C. H. R. (1998). Community structure and bioturbation potential of macrofauna at four North Sea stations with contrasting food supply. Mar. Ecol. Prog. Ser. 173, 67-83. doi: 10.3354/ meps173067

de-la-Ossa-Carretero, J. A., Del-Pilar-Ruso, Y., Giménez-Casalduero, F., SánchezLizaso, J. L., and Dauvin, J. C. (2012). Sensitivity of amphipods to sewage pollution. Estuar. Coast Shelf Sci. 96, 129-138. doi: 10.1016/j.ecss.2011. 10.020

de-la-Ossa-Carretero, J. A., Del-Pilar-Ruso, Y., Giménez-Casalduero, F., and Sánchez-Lizaso, J. L. (2016). Amphipoda assemblages in a disturbed area (Alicante, Spain, Western Mediterranean). Mar. Ecol. 37, 503-517. doi: 10.1111/ maec.12264

Díaz, E. R., and McQuaid, C. D. (2011). A spatially explicit approach to trophic interactions and landscape formation: patchiness in small-scale variability of grazing effects along an intertidal stress gradient. J. Ecol. 99, 416-430. doi: 10.1111/j.1365-2745.2010.01779.x

Dixit, A. M., Kumar, P., Kumar, L., Pathak, K. D., and Patel, M. I. (2010). Economic Valuation of Coral Reef Systems in Gulf of Kachchh. Final Report of World Bank Aided Integrated Coastal Zone Management (ICZM) Project. Gujarat: Gujarat Ecology Commission, 158.

Dray, S., and Dufour, A. B. (2007). The ade4 package: implementing the duality diagram for ecologists. J. Stat. Softw. 22, 1-20.

Duffy, J. E. (2006). Biodiversity and the functioning of seagrass ecosystems. Mar. Ecol. Prog. Ser. 311, 233-250. doi: 10.3354/meps311233

Duffy, J. E., and Hay, M. E. (2000). Strong impacts of grazing amphipods on the organization of a benthic community. Ecol. Monogr. 70, 237-263. doi: 10.1890/ 0012-96152000070[0237:SIOGAO]2.0.CO;2

Frid, C. L. J., and Caswell, B. A. (2015). Is long-term ecological functioning stable: the case of the marine benthos? J. Sea Res. 98, 15-23. doi: 10.1016/j.seares.2014. 08.003

Gallmetzer, I., Pflugfelder, B., Zekely, J., and Ott, J. A. (2005). Macrofauna diversity in Posidonia oceanica detritus: distribution and diversity of mobile macrofauna in shallow sublittoral accumulations of Posidonia oceanica detritus. Mar. Biol. 147, 517-523. doi: 10.1007/s00227-005-1594-9

Gamito, S., and Furtado, R. (2009). Feeding diversity in macroinvertebrate communities: a contribution to estimate the ecological status in shallow waters. Ecol. Indicat. 9, 1009-1019. doi: 10.1016/j.ecolind.2008.11.012

Gestoso, I., Olabarria, C., and Troncoso, J. S. (2014). Selection of habitat by a marine amphipod. Mar. Ecol. 35, 103-110. doi: 10.1111/maec.12068

Gravely, F. H. (1927). The Littoral Fauna of Krusadai Island in the Gulf of Mannar. Amphipoda Gammaridea. Bull. Madras Govt. Mus. not. Hist. 1, 123-124.

Guerra-García, J. M., De Figueroa, J. T., Navarro-Barranco, C., Ros, M., SánchezMoyano, J. E., and Moreira, J. (2014). Dietary analysis of the marine Amphipoda (Crustacea: Peracarida) from the Iberian Peninsula. J. Sea Res. 85, 508-517. doi: 10.1016/j.seares.2013.08.006

Guerra-García, J. M., Ganesh, T., Jaikumar, M., and Raman, A. V. (2010). Caprellids (Crustacea: Amphipoda) from India. Helgol. Mar. Res. 64:297. doi: 10.1007/s10152-009-0183-6

Guerra-García, J. M., and Tierno de Figueroa, J. M. (2009). What do caprellids feed on? Mar. Biol. 156, 1881-1890. doi: 10.1007/s00227-009-1220-3 
Hacker, S. D., and Steneck, R. S. (1990). Habitat architecture and the abundance and body-size dependent habitat selection of a phytal amphipod. Ecology 71, 2269-2285. doi: 10.2307/1938638

Harley, C. D., Randall Hughes, A., Hultgren, K. M., Miner, B. G., Sorte, C. J., Thornber, C. S., et al. (2006). The impacts of climate change in coastal marine systems. Ecol. Let. 9, 228-241. doi: 10.1111/j.1461-0248.2005. 00871.x

Hinchey, E. K., Schaffner, L. C., Hoar, C. C., Vogt, B. W., and Batte, L. P. (2006). Responses of estuarine benthic invertebrates to sediment burial: the importance of mobility and adaptation. Hydrobiologia 556, 85-98. doi: 10.1007/s10750005-1029-0

Jażdżewska, A. M., and Siciński, J. (2017). Assemblages and habitat preferences of soft bottom Antarctic Amphipoda: admiralty Bay case study. Polar Biol. 40, 845-1869. doi: 10.1007/s00300-017-2107-2

Jennings, S., Pinnegar, J. K., Polunin, N. V. C., and Boon, T. W. (2001). Weak cross-species relationships between body size and trophic level belie powerful size-basedtrophic structuring in fish communities. J. Anim. Ecol. 70, 934-944. doi: 10.1046/j.0021-8790.2001.00552.x

Kamboj, R. D. (2014). Biology and status of seagrasses in Gulf of Kachchh Marine National Park and Sanctuary India. Indian Ocean Turt. Newsl. 19, 9-11.

Kokarev, V. N., Vedenin, A. A., Basin, A. B., and Azovsky, A. I. (2017). Taxonomic and functional patterns of macrobenthic communities on a high-Arctic shelf: a case study from the Laptev. Sea. J. Sea Res. 129, 61-69. doi: 10.1016/j.seares. 2017.08.011

Kristensen, E. (1988). "Benthic fauna and biogeochemical processes in marine sediments: microbial activities and fluxes," in Nitrogen Cycling in Coastal Marine Environments, eds T. H. Blackburn and J. Sørensen (Vijayawada: SCOPE), 275-299.

Kristensen, E., Penha-Lopes, G., Delefosse, M., Valdemarsen, T., Quintana, C. O., and Banta, G. T. (2012). What is bioturbation? The need for a precise definition for fauna in aquatic sciences. Mar. Ecol. Prog. Ser. 446, 285-302. doi: 10.3354/ meps09506

Kumar, J. Y., Marimuthu, N., Geetha, S., Satyanarayana, C., Venkataraman, K., and Kamboj, R. D. (2014). Longitudinal variations of coral reef features in the Marine National Park, Gulf of Kachchh. J. Coast Conserv. 18, 167-175. doi: 10.1007/s11852-014-0303-6

Legeżyńska, J., Kêdra, M., and Walkusz, W. (2012). When season does not matter: summer and winter trophic ecology of Arctic amphipods. Hydrobiologia 684, 189-214. doi: 10.1007/s10750-011-0982-z

Lewis, J. R. (1964). The Ecology of Rocky Shore. London: English University Press.

Lincoln, R. J. (1979). British Marine Amphipoda: Gammaridea (No. 818). London: British Museum.

Lourido, A., Moreira, J., and Troncoso, J. S. (2008). Assemblages of peracarid crustaceans in subtidal sediments from the Ría de Aldán (Galicia, NW Spain). Helgol. Mar. Res. 62, 289-301. doi: 10.1007/s10152-008-0116-9

Lyla, P. S., Velvizhi, S., and Ajmal Khan, S. (1998). Brackishwater Amphipods of Parangipettai Coast. Chidambaram: Annamalai University, 1-80.

Macdonald, T. A., Burd, B. J., Macdonald, V. I., and Van Roodselaar, A. (2010). Taxonomic and Feeding Guild Classification for the Marine Benthic Macroinvertebrates of the Strait of Georgia, British Columbia. Ottawa, ON: Ocean Sciences Division, Fisheries and Ocean Canada. 63.

Marine Species Traits editorial board (2019). Marine Species Traits. Available online at: http://www.marinespecies.org/traits (accessed October 17, 2019).

MarLIN (2006). BIOTIC - Biological Traits Information Catalogue. Marine Life Information Network. Plymouth: Marine Biological Association of the United Kingdom.

Marques, J. C., and Bellan-Santini, D. (1991). Gammaridea and Caprellidea (Crustacea - Amphipoda) of the Portuguese south-western continental shelf: taxonomy and distributional ecology. Bijdr. Dierkd. 61, 65-87. doi: 10.1163/ 26660644-06102001

McBane, C. D., and Croker, R. A. (1983). Animal-algal relationships of the amphipod Hyale nilssoni (Rathke) in the rocky intertidal. J. Crust. Biol. 3, 592-601. doi: 10.1163/193724083X00256

McLachlan, A. (1983). "Sandy beach ecology - a review," in Sandy Beaches as Ecosystem, eds A. McLachlan and T. Erasmus (The Hague: Junk Publishers), 321-380. doi: 10.1007/978-94-017-2938-3_25

Mejaes, B. A., Poore, A. G. B., and Thiel, M. (2015). "Crustaceans inhabiting domiciles excavated from macrophytes and stone," in The Life Styles and Feeding
Biology of the Crustacea, Nat. His. Crustacea Ser., eds M. Thiel and L. Watling (Oxford: Oxford Univ Press), 2, 118-144.

Menge, B. A., and Branch, G. M. (2001). "Rocky intertidal communities," in Marine Community Ecology, eds M. D. Bertness, S. D. Gaines, and M. E. Hay (Sunderland: Sinauer Associates), 221-251.

Menge, B. A., Farrel, T. M., Olson, A. N., Tamelen, P., and Turner, T. (1993). Algal recruitment and the maintenance of a plant mosaic in the low intertidal region of the Oregon coast. J. Exp. Mar. Biol. Ecol. 170, 91-116. doi: 10.1016/00220981(93)90131-7

Menge, B. A., and Sutherland, J. P. (1987). Community regulation: variation in disturbance, competition, and predation in relation to environmental stress and recruitment. Am. Nat. 130, 730-757. doi: 10.1086/284741

Mills, E. L. (1967). A reexamination of some species of Ampelisca (Crustacea: Amphipoda) from the east coast of North America. Can. J. Zool. 45, 635-652. doi: 10.1139/z67-080

Mondal, N., Rajkumar, M., Sun, J., Kundu, S., Ajmal, S., and Jean, K. (2010). Biodiversity of brackish water amphipods (crustacean) in two estuaries, southeast coast of India. Environ. Monit. Asses. 171, 471-486. doi: 10.1007/ s10661-009-1292-z

Mouillot, D., Spatharis, S., Reizopoulou, S., Laugier, T., Sabetta, L., Basset, A., et al. (2006). Alternatives to taxonomic-based approaches to assess changes in transitional water communities. Aquat. Conserv. Mar. Freshw. Ecosyst. 16, 469-482. doi: 10.1002/aqc.769

Myers, A. A., Sreepada, R. A., and Sanaye, S. V. (2019). A new species of Grandidierella Coutière, 1904, G. nioensis sp. nov. (Amphipoda, Aoridae), from the east coast of India. Zootaxa 4544, 119-124. doi: 10.11646/zootaxa.4544.1.7

Myers, A. A., Trivedi, J. N., Gosavi, S., and Vachhrajani, K. D. (2018). Elasmopus sivaprakasami sp. nov., a new species of amphipod (Senticaudata, Maeridae) from Gujarat State, India. Zootaxa 4402, 182-188. doi: 10.11646/zootaxa.4402. 1.10

Nair, K. K. C., Gopalakrishnan, T. C., Venugopal, P., Peter, M. G., Jayalakshmi, K. V., and Rao, T. S. S. (1983). Population dynamics of estuarine amphipods in cochin backwaters. Mar. Ecol. Prog. Ser. 10, 289-295. doi: 10.3354/meps 010289

Narayanan, B., and Sivadas, P. (1986). Studies on the intertidal macrofauna of the sandy beach at Kavaratti Atoll (Lakshadweep). Mahasagar 19, 11-22.

National Institute of Oceanography [NIO] (2018). Comprehensive Monitoring of Marine Ecology off Vadinar (April - 2018). Dona Paula: National Institute of Oceanography.

Newell, R. C. (1970). The biology of intertidal animals. Logos Press Ltd, London, 555 PP. of bottom trawling on ecosystem functioning. J. Exp. Mar. Biol. Ecol. 366, 123-133. doi: 10.1016/j.jembe.2008.07.036

Oksanen, J., Blanchet, F. G., Friendly, M., Kindt, R., Legendre, P., McGlinn, D., et al. (2016). Vegan: Community Ecology Package. R Package Version 2.4- 6. Available online at: https://CRAN.R-project.org/package=vegan (accessed November 10, 2019).

Oliva-Rivera, J. J. (2003). The amphipod fauna of Banco Chinchorro, Quintana Roo, Mexico with ecological notes. Bull. Mar. Sci. 73, 77-89.

Olsgard, F., Schaanning, M. T., Widdicombe, S., Kendall, M. A., and Austen, M. C. (2008). Effects of bottom trawling on ecosystem functioning. J. Exp. Mar. Biol. Ecol. 366, 123-133.

Pacheco, A. S., González, M. T., Bremner, J., Oliva, M., Heilmayer, O., and Laudien, J. (2011). Functional diversity of marine macrobenthic communities from sublittoral soft-sediment habitats off northern Chile. Helgol. Mar. Res. 65:413. doi: 10.1007/s10152-010-0238-8

Paganelli, D., Marchini, A., and Occhipinti-Ambrogi, A. (2012). Functional structure of marine benthic assemblages using biological traits analysis (BTA): a study along the emiliaromagna coastline (Italy, north-west adriatic sea). Estuar. Coast Shelf Sci. 96, 245-256. doi: 10.1016/j.ecss.2011.11.014

Paine, R. T. (1969). The Pisaster-Tegula interaction: prey patches, predator food preference, and intertidal community structure. Ecology 50, 950-962. doi: $10.2307 / 1936888$

Paine, R. T. (1974). Intertidal community structure. Oecologia 15, 93-120. doi: $10.2307 / 1350837$

Pandey, V., and Thiruchitrambalam, G. (2018). Spatial and temporal variability in the vertical distribution of gastropods on the rocky shores along the east coast of South Andaman Island. India. Mar. Biodiver. 49, 633-645. doi: 10.1007/s12526017-0838-5 
Parker, J. G. (1984). The distribution of the subtidal Amphipoda in Belfast Lough in relation to sediment types. Ophelia 23, 119-140. doi: 10.1080/00785326.1984. 10426608

Parmar, H., Barad, D., and Parasharya, D. (2015). Reef dependent ichthyofauna of the Gulf of Kachchh, Gujarat, Western India. Int. J. Fish. Aquat. Stud. 2, 33-37.

Paz-Ríos, C. E., and Ardisson, P. L. (2018). Intra-annual variability of a Benthic Amphipod Assemblage (Crustacea: Amphipoda) in a tropical shallow coastal environment. Thalassas 34, 289-300. doi: 10.1007/s41208-017-0063-9

Paz-Ríos, C. E., Simões, N., and Pech, D. (2019). Species richness and spatial distribution of benthic amphipods (Crustacea: Peracarida) in the Alacranes Reef National Park, Gulf of Mexico. Mar. Biodivers. 49, 673-682. doi: 10.1007/ s12526-017-0843-8

Pearson, T. H. (2001). Functional group ecology in soft-sediment marine benthos: the role of bioturbation. Oceanogr. Mar. Biol. Annu. Rev. 39, 233-267. doi: 10.1016/0022-0981(92)90177-c

Penrith, M. L., and Kensley, B. F. (1970). The constitution of the intertidal fauna of rocky shores of South West Africa Part. 1. Luderitzbucht. Cimbebasia 1, 191-239.

Piló, D., Ben-Hamadou, R., Pereira, F., Carriço, A., Pereira, P., Corzo, A., et al. (2016). How functional traits of estuarine macrobenthic assemblages respond to metal contamination? Ecol. Indic. 71, 645-659. doi: 10.1016/j.ecolind.2016. 07.019

Queirós, A. M., Birchenough, S. N., Bremner, J., Godbold, J. A., Parker, R. E., Romero-Ramirez, A., et al. (2013). A bioturbation classification of $\mathrm{E}$ uropean marine infaunal invertebrates. Ecol. Evol. 3, 3958-3985. doi: 10.1002/ece3.769

Raj, B. S. (1927). The Littoral Fauna of the Krusadai Island in the Gulf of Mannar. Caprellidea. Bull. Madras Govt. Mus. Nat. Hist. 1, 125-128.

Raja, S., Lyla, P. S., and Khan, S. A. (2013). Diversity of amphipods in the continental shelf sediments of southeast coast of India. J. Mar. Biol. Assoc. India 55, 35-41. doi: 10.6024/jmbai.2013.55.1.01742.06

Rao, C. R. (1982). Diversity and dissimilarity coefficients: a unified approach. Theor. Popul. Biol. 21, 24-43. doi: 10.1016/0040-5809(82)90004-1

Rehitha, T. V., Madhu, N. V., Vineetha, G., Vipindas, P. V., and Lallu, K. R. (2019). Macrobenthic fauna with special reference to the ecology and population structure of a tubicolous amphipod, Chelicorophium madrasensis (Nayar, 1950) in a tropical estuary, southwest coast of India. Mar. Biodiv. 49, 1013-1026. doi: $10.1007 / \mathrm{s} 12526-018-0886-5$

Reise, K. (2002). Sediment mediated species interactions in coastal waters. J. Sea Res. 48, 127-141. doi: 10.1016/S1385-1101(02)00150-8

Rhoads, D. C. (1974). Organism-sediment relations on the muddy sea floor. Oceanogr. Mar. Bull. A Rev. 12, 263-300.

Rivonker, C. U., and Sangodkar, U. M. X. (1997). Macrofaunal density along the intertidal region of three atolls of Lakshadweep, Arabian Sea. Ind. J. Fish 44, 345-352.

Roy, S., Salvi, H., Brahmbhatt, B., Vaghela, N., Das, L., and Pathak, B. (2015). Diversity and distribution of seaweeds in selected reefs and island in Gulf of Kachchh. Seaweed Res. Utiln. 37, 12-19.

Sanz-Lázaro, C., and Marín, A. (2011). Diversity patterns of benthic macrofauna caused by marine fish farming. Diversity 3, 176-199. doi: 10.3390/d3020176

Satyanarayana, C. H., and Ramakrishna. (2009). Handbook on Hard Corals of Gulf of Kachchh. Kolkata: Zoological Survey of India.

Sfriso, A., and Marcomini, A. (1997). Macrophyte production in a shallow coastal lagoon. Part 1. Coupling with chemico-physical parameters and nutrient concentrations in waters. Mar. Environ. Res. 44, 351-375. doi: 10.1016/S01411136(97)00012-3

Sheader, M. (1977). Production and population dynamics of Ampelisca tenuicornis (Amphipoda) with notes on the biology of its parasite Sphaeronella longipes (Copepoda). J. Mar. Biol. Ass. U. K. 57, 955-968. doi: 10.1017/ S0025315400026047

Sindorf, V., Cowburn, B., and Sluka, R. D. (2015). Rocky intertidal fish assemblage of the Watamu Marine National Park, Kenya (Western Indian Ocean). Environ. Biol. Fish. 98, 1777-1785. doi: 10.1007/s10641-0150397-1

Sinha, M. P. (1997). Recent Advances in Ecobiological Research, Vol. 1. Ladakh: A.P.H. Publication, 630

Southward, A. J. (1958). The zonation of plants and animals on rocky sea-shores. Biol. Rev. 33, 1337-1177. doi: 10.1111/j.1469-185X.1958.tb01305.x
Southwood, T. R. E. (1977). Habitat, the templet for ecological strategies? J. Anim. Ecol. 46, 337-365.

Srinivas, T., Sukumaran, S., Mulik, J., and Dias, H. Q. (2019). Community structure of benthic amphipods in four estuaries of northwest India. Reg. Stud. Mar. Sci. 27:100532. doi: $10.1016 /$ j.rsma.2019.100532

Subba Rao, N. Y., and Sastry, D. R. K. (2005). Fauna of Marine National Park, Gulf of Kachchh (Gujarat): an overview. Conserv. Area Ser. 23, 1-79.

Sukumaran, S., Vijapure, T., Mulik, J., Rokade, M. A., and Gajbhiye, S. N. (2013). Macrobenthos in anthropogenically influenced zones of a coralline marine protected area in the Gulf of Kachchh, India. J. Sea Res. 76, 39-49. doi: 10.1016/ j.seares.2012.11.001

Surya Rao, K. V. (1972). Intertidal amphipods from the Indian coast. Proc. Indian Nat. Sci. Acad. 38, 190-205.

Thomas, J. D. (1993). Biological monitoring and tropical biodiversity in marine environments: a critique with recommendations, and comments on the use of amphipods as bioindicators. J. Nat. His. 27, 795-806. doi: 10.1080/ 00222939300770481

Trivedi, J. N., Gadhavi, M. K., and Vachhrajani, K. D. (2012). Diversity and habitat preference of brachyuran crabs in Gulf of Kutch, Gujarat, India. Arthropods 1:13.

Underwood, A. J. (1981). Structure of a rocky intertidal community in New South Wales: patterns of vertical distribution and seasonal changes. J. Exp. Mar. Biol. Ecol. 51, 57-85. doi: 10.1016/0022-0981(81)90154-4

Underwood, A. J. (2000). Experimental ecology of rocky intertidal habitats: what are we learning? J. Exp. Mar. Biol. Ecol. 250, 51-76. doi: 10.1016/S0022-0981(00) 00179-9

Valdivia, N., Scrosati, R. A., Molis, M., and Knox, A. S. (2011). Variation in community structure across vertical intertidal stress gradients: how does it compare with horizontal variation at different scales? PLoS One 6:e24062. doi: 10.1371/journal.pone.0024062

van der Linden, P., Marchini, A., Smith, C. J., Dolbeth, M., Simone, L. R. L., Marques, J. C., et al. (2017). Functional changes in polychaete and mollusc communities in two tropical estuaries. Estuar. Coast Shelf Sci. 187, 62-73. doi: 10.1016/j.ecss.2016.12.019

Vázquez-Luis, M., Borg, J. A., Sanchez-Jerez, P., and Bayle-Sempere, J. T. (2012). Habitat colonisation by amphipods: comparison between native and alien algae. J. Exp. Mar. Biol. Ecol. 432, 162-170. doi: 10.1016/j.jembe.2012.07.016

Warwick, R. M. (1993). Environmental impact studies on marine communities: pragmatical considerations. Aust. J. Ecol. 18, 63-80. doi: 10.1111/j.1442-9993. 1993.tb00435.x

Webb, T. J., Tyler, E., and Somerfield, P. J. (2009). Life history mediates large-scale population ecology in marine benthic taxa. Mar. Ecol. Prog. Ser. 396, 239-306. doi: $10.3354 /$ meps 08253

Wildish, D. J. (1988). Ecology and natural history of aquatic Talitroidea. Can. J. Zool. 66, 2340-2359. doi: 10.1139/z88-349

Wong, M. C., and Dowd, M. (2015). Patterns in taxonomic and functional diversity of macrobenthic invertebrates across seagrass habitats: a case study in Atlantic Canada. Estuar. Coast. 38, 2323-2336. doi: 10.1007/s12237-015-9967-x

Yu, O. H., Soh, H. Y., and Suh, H. L. (2002). Seasonal zonation patterns of benthic amphipods in a sandy shore surf zone of Korea. J. Crustacean Biol. 22, 459-466. doi: 10.1163/20021975-99990253

Zheng, X., Huang, L., Wang, Q., and Lin, R. (2014). Amphipods fail to suppress the accumulation of Ulva lactuca biomass in eutrophic Yundang Lagoon. Acta Oceanol. Sin. 33, 155-162. doi: 10.1007/s13131-0140532-4

Conflict of Interest: The authors declare that the research was conducted in the absence of any commercial or financial relationships that could be construed as a potential conflict of interest.

Copyright () 2020 Srinivas, Sukumaran, Neetu and Ramesh Babu. This is an openaccess article distributed under the terms of the Creative Commons Attribution License (CC BY). The use, distribution or reproduction in other forums is permitted, provided the original author(s) and the copyright owner(s) are credited and that the original publication in this journal is cited, in accordance with accepted academic practice. No use, distribution or reproduction is permitted which does not comply with these terms. 